\title{
Article \\ Novel Cold-Adapted Recombinant Laccase KbLcc1 from Kabatiella bupleuri G3 IBMiP as a Green Catalyst in Biotransformation
}

\author{
Katarzyna M. Wiśniewska, Aleksandra Twarda-Clapa and Aneta M. Białkowska * \\ Institute of Molecular and Industrial Biotechnology, Lodz University of Technology, Stefanowskiego 2/22, \\ 90-537 Łódź, Poland; kma.wisniewska@gmail.com (K.M.W.); aleksandra.twarda-clapa@p.lodz.pl (A.T.-C.) \\ * Correspondence: aneta.bialkowska@p.lodz.pl
}

Citation: Wiśniewska, K.M.; Twarda-Clapa, A.; Białkowska, A.M. Novel Cold-Adapted Recombinant Laccase KbLcc1 from Kabatiella bupleuri G3 IBMiP as a Green Catalyst in Biotransformation. Int. J. Mol. Sci. 2021, 22, 9593. https://doi.org/ $10.3390 /$ ijms22179593

Academic Editor: Vladimír Křen

Received: 10 August 2021

Accepted: 1 September 2021

Published: 4 September 2021

Publisher's Note: MDPI stays neutral with regard to jurisdictional claims in published maps and institutional affiliations.

Copyright: (c) 2021 by the authors. Licensee MDPI, Basel, Switzerland. This article is an open access article distributed under the terms and conditions of the Creative Commons Attribution (CC BY) license (https:// creativecommons.org/licenses/by/ $4.0 /)$.
Abstract: Cold-adapted enzymes are useful tools in the organic syntheses conducted in mixed aqueous-organic or non-aqueous solvents due to their molecular flexibility that stabilizes the proteins in low water activity environments. A novel psychrophilic laccase gene from Kabatiella bupleuri, G3 IBMiP, was spliced by Overlap-Extension PCR (OE-PCR) and expressed in Pichia pastoris. Purified recombinant $\mathrm{KbLcc1}$ laccase has an optimal temperature of $30^{\circ} \mathrm{C}$ and $\mathrm{pH}$ of 3.5, 5.5, 6.0, and 7.0 in the reaction with 2,2'-azino-bis(3-ethylbenzothiazoline-6-sulfonic acid) (ABTS), guaiacol, sinapic acid, and syringaldazine, respectively. Moreover, laccase $\mathrm{KbLccl}$ is highly thermolabile, as it loses $40 \%$ of activity after $30 \mathrm{~min}$ at $40^{\circ} \mathrm{C}$ and is inactivated at $50^{\circ} \mathrm{C}$ after the same period of incubation. The new enzyme remained active with $1 \mathrm{mM}$ of $\mathrm{Ni}^{2+}, \mathrm{Cu}^{2+}, \mathrm{Mn}^{2+}$, and $\mathrm{Zn}^{2+}$ and with $2 \mathrm{mM}$ of $\mathrm{Co}^{2+}, \mathrm{Ca}^{2+}$, and $\mathrm{Mg}^{2+}$, but $\mathrm{Fe}^{2+}$ greatly inhibited the laccase activity. Moreover, $1 \%$ ethanol had no impact on KbLcc1, although acetone and ethyl acetate decreased the laccase activity. The presence of hexane $(40 \%, v / v)$ caused a $58 \%$ increase in activity. Laccase KbLcc1 could be applied in the decolorization of synthetic dyes and in the biotransformation of ferulic acid to vanillin. After 5 days of reaction at $20^{\circ} \mathrm{C}, \mathrm{pH} 3.5$, with $1 \mathrm{mM}$ ABTS as a mediator, the vanillin concentration was $21.9 \mathrm{mg} / \mathrm{L}$ and the molar yield of transformation reached $14.39 \%$.

Keywords: psychrophilic laccase; Kabatiella bupleuri; recombinant enzyme; Pichia pastoris; decolorization; biotransformation; vanillin

\section{Introduction}

Laccases (EC 1.10.3.2, benzenediol:oxygen oxidoreductases) are multicopper oxidases which catalyze the oxidation of a broad range of substrates, e.g., phenolic and polyphenolic compounds, polyamines, aryl diamines, aminophenols, and lignins. Depending on the value of redox potential (RP), two groups of laccases are distinguished, namely low RP $(0.4-0.6 \mathrm{~V})$ and high $\mathrm{RP}(0.6-0.8 \mathrm{~V})$ [1]. When the redox potential of laccase is lower than the RP of the substrate, the enzyme cannot oxidize it. In that situation, it is necessary to use small molecules capable to act as electron transfer mediators, such as $2,2^{\prime}$-azino-bis (3-ethylbenzothiazoline-6-sulfonic acid) (ABTS) or 1-hydroxybanzotriazole (HBT). Mediators added to reaction mixtures enhance the use of these enzymes for industrial processes, including the detoxification of industrial dyes, delignification of lignocellulosic biomass, and bioremediation of xenobiotic compounds, polycyclic aromatic hydrocarbons, and pesticides [2].

The application of a laccase in industrial and environmental processes requires a large amount of an enzyme. Therefore, it is important to identify a highly efficient microorganism or to develop an efficient expression system to produce a heterologous laccase. For the expression of recombinant laccases and laccase-like enzymes, several expression systems based on bacteria (Escherichia coli), plants (Arabidopsis thaliana), yeast (Pichia pastoris, Saccharomyces cerevisiae), and filamentous fungi (Aspergillus niger, Aspergillus oryzae, Trichoderma 
resei) have been used. Considering that these enzymes are glycoproteins that require glycosylation for their activity, bacterial systems are used less often [3]. Due to the fact that the optimization of gene expression by directed evolution methods is complicated to achieve in plants and filamentous fungi, the cloning and expression of fungal laccases and laccase-like enzymes is usually performed in the yeast [4]. The main advantages of the yeast systems include growth on solid medium as individual colonies, absence of laccase genes to be expressed, and the secretion of recombinant proteins into the medium, providing simple activity detection without a lysis step. The most commonly used yeast species for laccase and laccase-like enzyme production are S. cerevisiae and P. pastoris [5].

Laccases show great potential for use in many industrial processes, including the paper industry for bleaching pulp [6], food industry for wine stabilization by removing excessive phenolic compounds [7], in the processes of detoxification [8,9] and decolorization $[10,11]$ of sewage sludge, as well as in the degradation of xenobiotics [12-14]. The use of laccases in organic syntheses is particularly interesting and promising. Laccase-mediated processes are used, inter alia, for the preparation of geranial, decanal, and 3,4-dimethoxybenzyl aldehyde [15]. In turn, the reactions of direct oxidation by laccase are used for the dimerization of resveratrol [16], rutin, and epigallocatechin gallate [17,18], as well as for the production of coloring substances for the cosmetics [19], textile [20], and food industries [21].

Vanillin (4-hydroxy-3-methoxybenzaldehyde) is the main flavor of vanilla pod (2.5-4.5\% of dry weight). To date, the most important source of vanillin remains chemical synthesis using guaiacol and lignin as a starting material. Recent advances in biotechnology have allowed for a bioengineering approach to the synthesis of vanillin. These new methods are based on the bioconversion of certain natural substrates, such as lignin, ferulic acid, eugenol, isoeugenol, and phenolic stilbenes, etc., using microorganisms such as fungi, bacteria, plant cells, or their genetically engineered counterparts [22]. The bioconversion of ferulic acid is one of the most intensively studied process of vanillin production. Many microorganisms, including Streptomyces sannanensis [23], A. niger [24], Bacillus subtilis [25] Amycolatopsis sp. [26], and Pycnoporus cinnabarinus [27], have been described as potential producers of vanillin from ferulic acid. Moreover, Furuya and coworkers studied the production of vanillin by a coenzyme-independent decarboxylase/oxygenase two-stage process [28].

In this study, a new cold-adapted laccase-like enzyme from Kabatiella bupleuri G3 IBMiP was expressed in P. pastoris. In our previous work, a novel laccase-producing yeastlike fungus, K. bupleuri G3 IBMiP, was identified, and an efficient secretion of the new enzyme was optimized [29]. Now, the coding sequence of KbLcc1 gene was obtained using Overlap-Extension PCR (OE-PCR), known as splicing in vitro. The recombinant protein was purified and characterized in terms of the optimal reaction conditions $(\mathrm{pH}$ and temperature), stability at different $\mathrm{pH}$ and temperature, in the presence of metal ions and organic solvents, and substrate specificity. The last part of study describes the application of KbLcc1 laccase-like enzyme in the decolorization of synthetic dyes and the transformation of ferulic acid into vanillin.

\section{Results and Discussion}

\subsection{Expression of KbLcc1 Laccase from K. bupleuri G3 IBMiP}

The genome of the psychrophilic yeast-like fungal strain (K. bupleuri G3 IBMiP) was sequenced and assembled in the SPAdes programme into 207 contigs of total 23,395,295 bp. N50 value was equal to 193,564 bp. Further, 10,172 gene-coding sequences were predicted in the Augustus programme, and a functional annotation was found for most of them.

The amino acid sequences were searched for the presence of domains characteristic for the investigated laccase in the Pfam database and Conserved Domain Database (CDD). Nine proteins containing the copper-binding domains were found, but only four of them contained domains characteristic for laccases (i.e., cd13854, cd13880, and cd13901 from CDD). Only three of them contained the signal peptide necessary for secretion of the enzyme. The extracellular psychrophilic laccase produced by K. bupleuri G3 IBMP was initially characterized to have a molecular mass of about $72 \mathrm{kDa}$ [29]. Therefore, the 
predicted masses of three potential laccases found in the genome were compared. The nucleotide sequence of KbLcc1 was found to contain an open reading frame (ORF) of $1938 \mathrm{bp}$ capable of coding for a protein of 649 amino acid residues, which corresponded to the molar weight of about $69 \mathrm{kDa}$. Domains characteristic for the laccases and copper binding sites were both found in this sequence. A comparison with the amino acid sequences database (non-redundant in GenBank) presented 86\% similarity of the enzyme from K. bupleuri to laccase-like multicopper oxidase from Aureobasidium subglaciale (XP_013344102.1) with $100 \%$ query coverage, whereas a comparison with the SWISSprot database (containing the sequences verified by the experts) revealed $59 \%$ similarity to the laccase from Neurospora crassa (P06811.3) with 83\% query coverage. Finally, the sequence of the reported enzyme KbLcc1 was aligned with eight sequences of laccases produced by fungi Ascomycota, including the enzyme from A. subglaciale that displayed the highest similarity to KbLcc1. Multiple sequence alignment allowed for the identification of four conservative regions in the KbLcc1 sequence that are characteristic for laccases and responsible for binding of the copper ions at the active site (Table 1, Figure 1).

Table 1. Accession numbers of sequences of laccases produced by Ascomycetes used for multiple sequence alignment.

\begin{tabular}{cc}
\hline Organism & GenBank Accession Number \\
\hline Kabatiella bupleuri G3 IBMiP & MZ292708 \\
Aureobasidium subglaciale EXF-2481 & XP_013344102.1 \\
Aureobasidium melanogenum CBS 110374 & KEQ63012.1 \\
Cenococcum geophilum 1.58 & OCL00379.1 \\
Paraphaeosphaeria sporulosa & OAG12255.1 \\
Glonium stellatum & OCL02255.1 \\
Cladophialophora carrionii & OCT53411.1 \\
Shiraia sp. SUPER-H168 & AHN82367.1 \\
Alternaria alternata & OAG13331.1 \\
\hline
\end{tabular}

Gene coding for the protein of interest contained one intron which had to be removed. To this end, the OE PCR method, also described as in vitro splicing, was applied (Figure 2). This is a simple, versatile technique for site-directed mutagenesis and gene splicing. Initial PCRs generate overlapping gene fragments that are then used as a template DNA for the next PCR to create a full-length product. Internal primers generate overlapping, complementary $3^{\prime}$ ends on the intermediate fragments and encode the nucleotides found at the junction of adjoining gene fragments. Overlapping strands hybridize at these $3^{\prime}$ end fragments in a subsequent PCR and are extended to the full-length coding sequence amplified by flanking primers. These primers can include restriction enzyme sites for further inserting the PCR product into an expression vector [30].

The KbLcc1 coding sequence flanked on $3^{\prime}$ and $5^{\prime}$ with the restriction sites for StuI and FseI restrictases was cloned into the yeast expression vector $\mathrm{pPINK} \alpha-\mathrm{HF}$ containing the $\alpha$-factor sequence, thereby enabling efficient protein secretion (construct scheme presented on Figure 3a).

Restriction analysis confirmed the correctness of the cloning-digestion with SpeI linearized the vector into a DNA molecule of $9827 \mathrm{bp}$, whereas the multiple digestions with SpeI, AscI, NdeI and EcoRI lead to the creation of five fragments of lengths: 1131, 1412, 1836, 2321, and $3127 \mathrm{bp}$ (Figure 3b). Due to the wide length range of the observed DNA fragments, it was impossible to accurately determine the length of the linear vector molecule with the insert. Nevertheless, the electrophoretic image shows that all vector particles have been digested, only one band is visible and no bands from circular particles are visible. In the case of multi-enzyme digestion, the estimated lengths of the fragments visible in the electrophoretic image correspond to those expected. The correctness of the insert sequence was further confirmed by sequencing and comparison with the sequence from the genome, which gave $100 \%$ identity. 
$\mathrm{N}$-terminal end of laccases

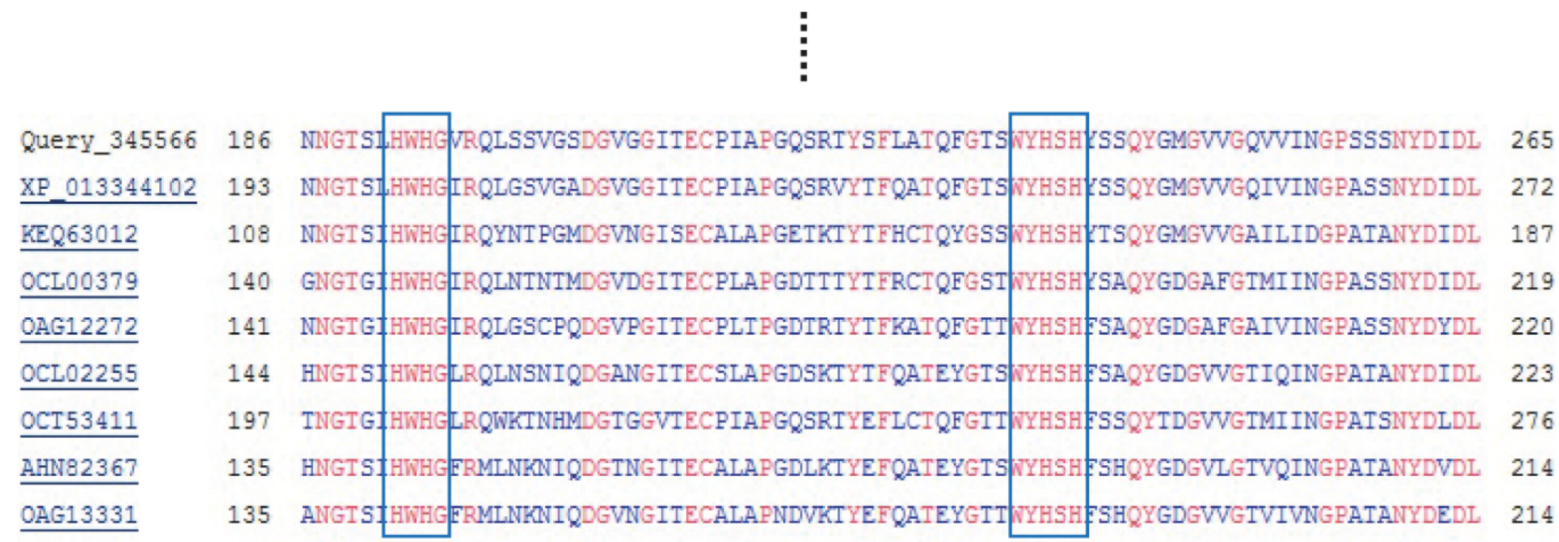

$\vdots$

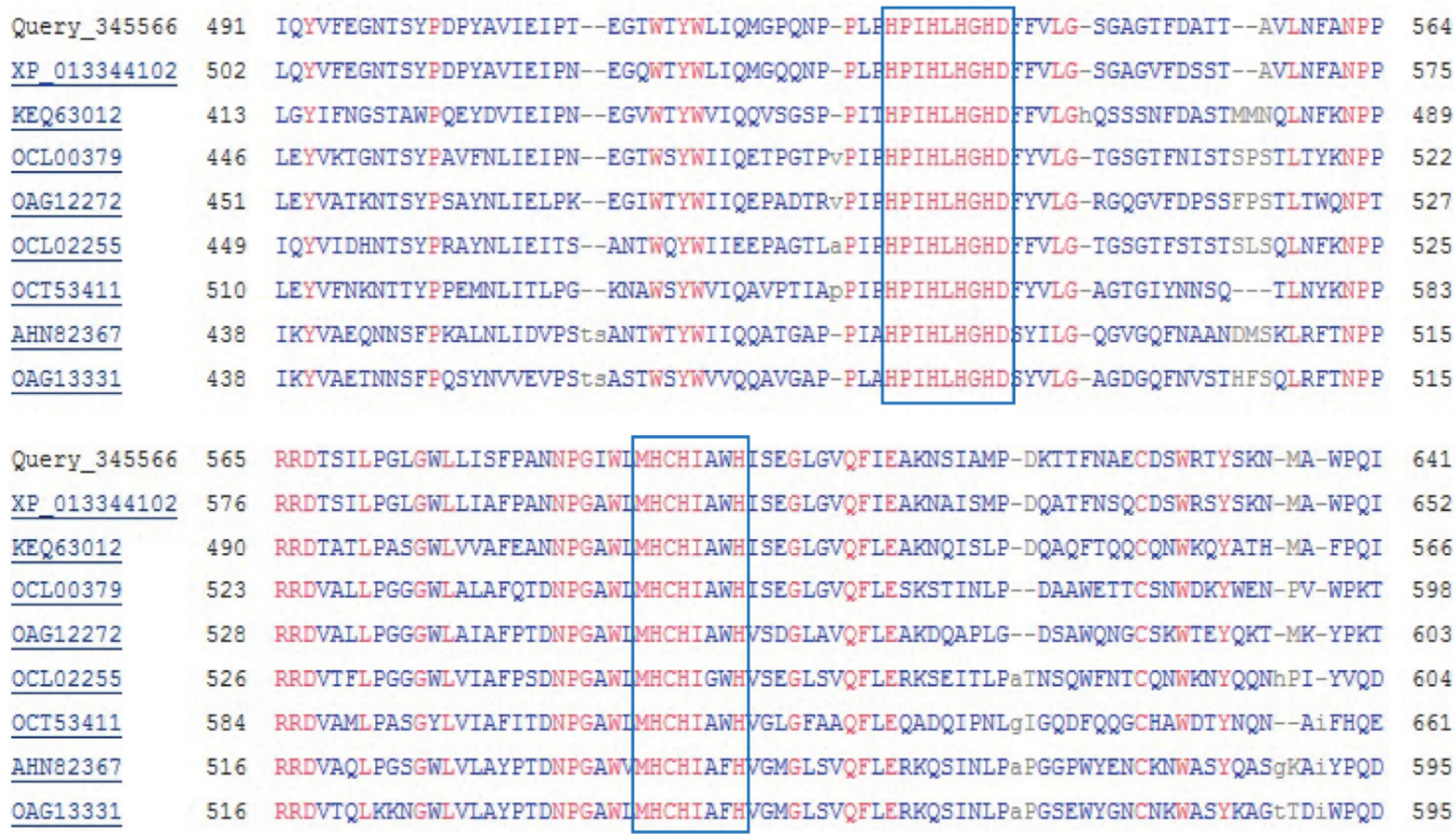

$\vdots$

\section{C-terminal end of laccases}

Figure 1. Multiple sequence alingment of laccase KbLcc1 and other laccase sequences from Ascomycetes using Constraintbased Multiple Alignment Tool (COBALT, https:/ / www.ncbi.nlm.nih.gov/tools/cobalt/cobalt.cgi, accessed on 15 July 2021); strong conservative copper-binding amino acids are indicated by blue frames. 


\section{KbLcc1 gene}

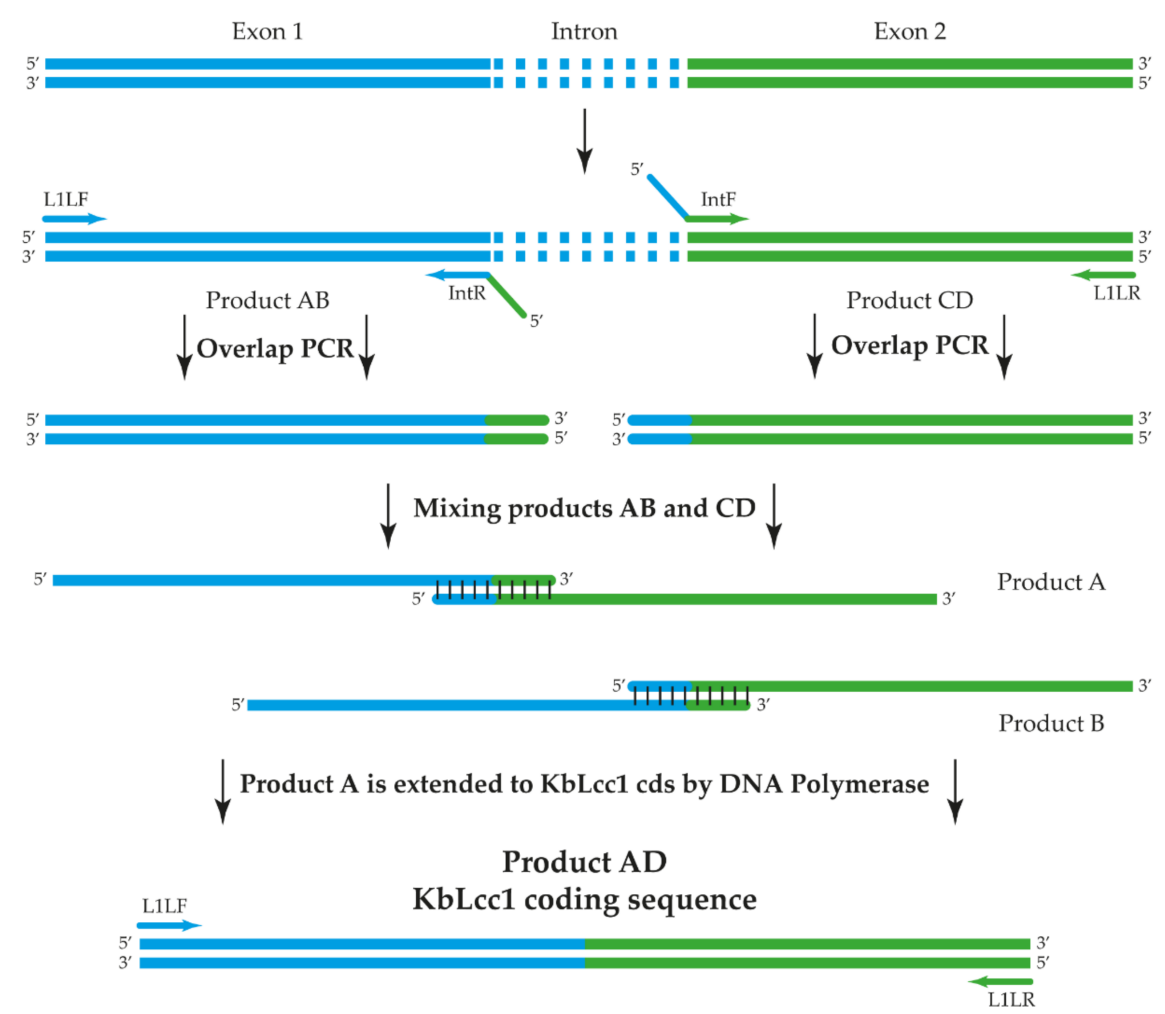

Figure 2. Scheme of Overall-Extension PCR reaction used to obtain of KbLcc1 laccase coding sequence.
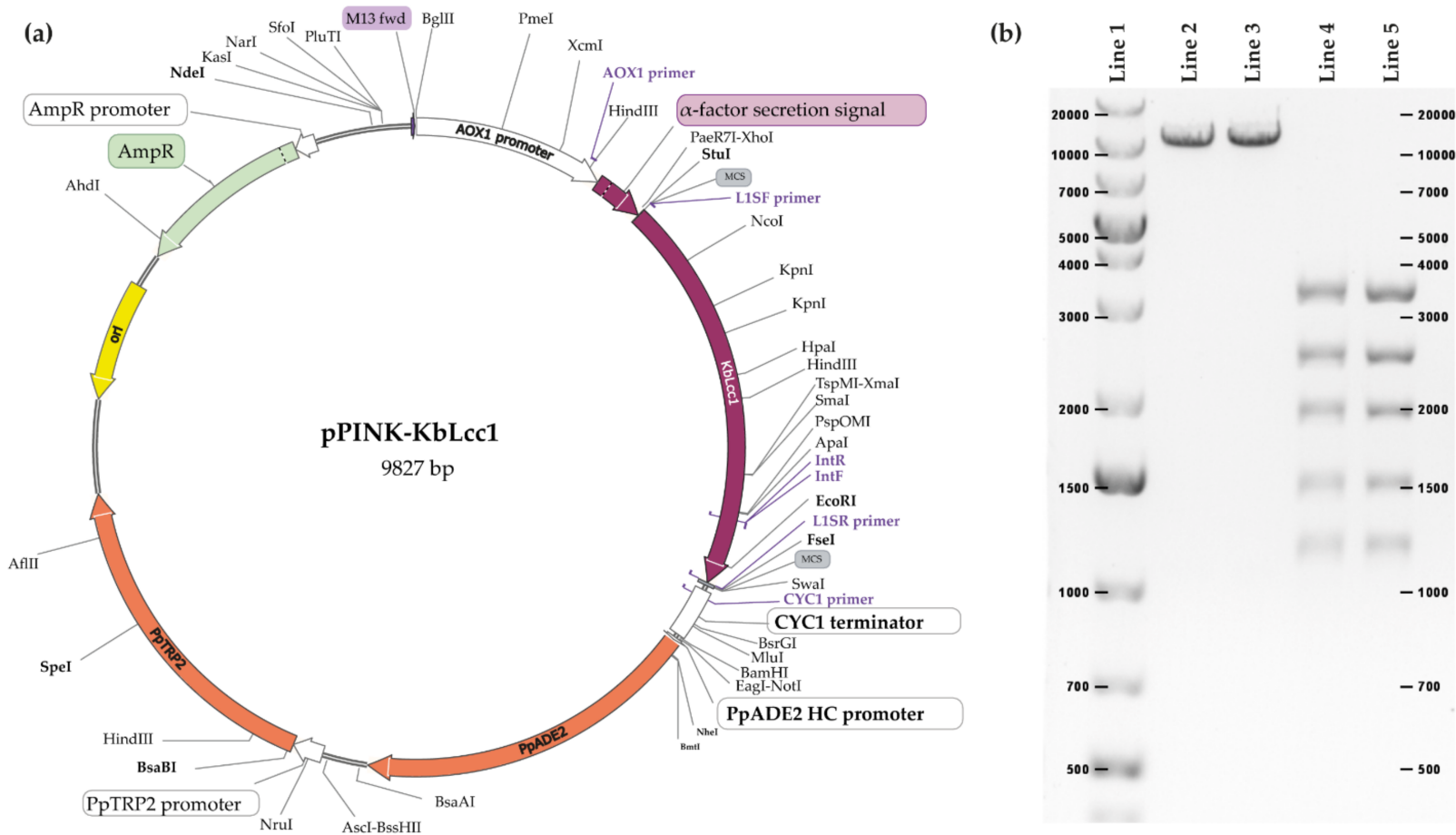

Figure 3. Construct of pPink $\alpha$-HF vector with the insert of laccase KbLcc1 coding sequence (a) and its restriction analysis (b); DNA fragments length marker (line 1), product after SpeI enzyme treatment (lines 2 and 3), products after multi-enzymes digestion with SpeI, AscI, NdeI and EcoRI (lines 4 and 5). 
The recombinant strains $P$. pastoris harboring pPINK $\alpha-\mathrm{HF}-\mathrm{KbLcc} 1$ were cultured in BMMY medium with methanol added daily to a final concentration of $0.5 \%$ to maintain enzyme induction. Laccase activity in the supernatant of the post-culture liquid reached 13.6 U/L after $120 \mathrm{~h}$ for clone CI. SDS-PAGE analysis showed that the secreted expression took place after $48 \mathrm{~h}$, and a constant rise in the amount of the recombinant protein was observed until $120 \mathrm{~h}$ (Figure $4 \mathrm{a}$ ).

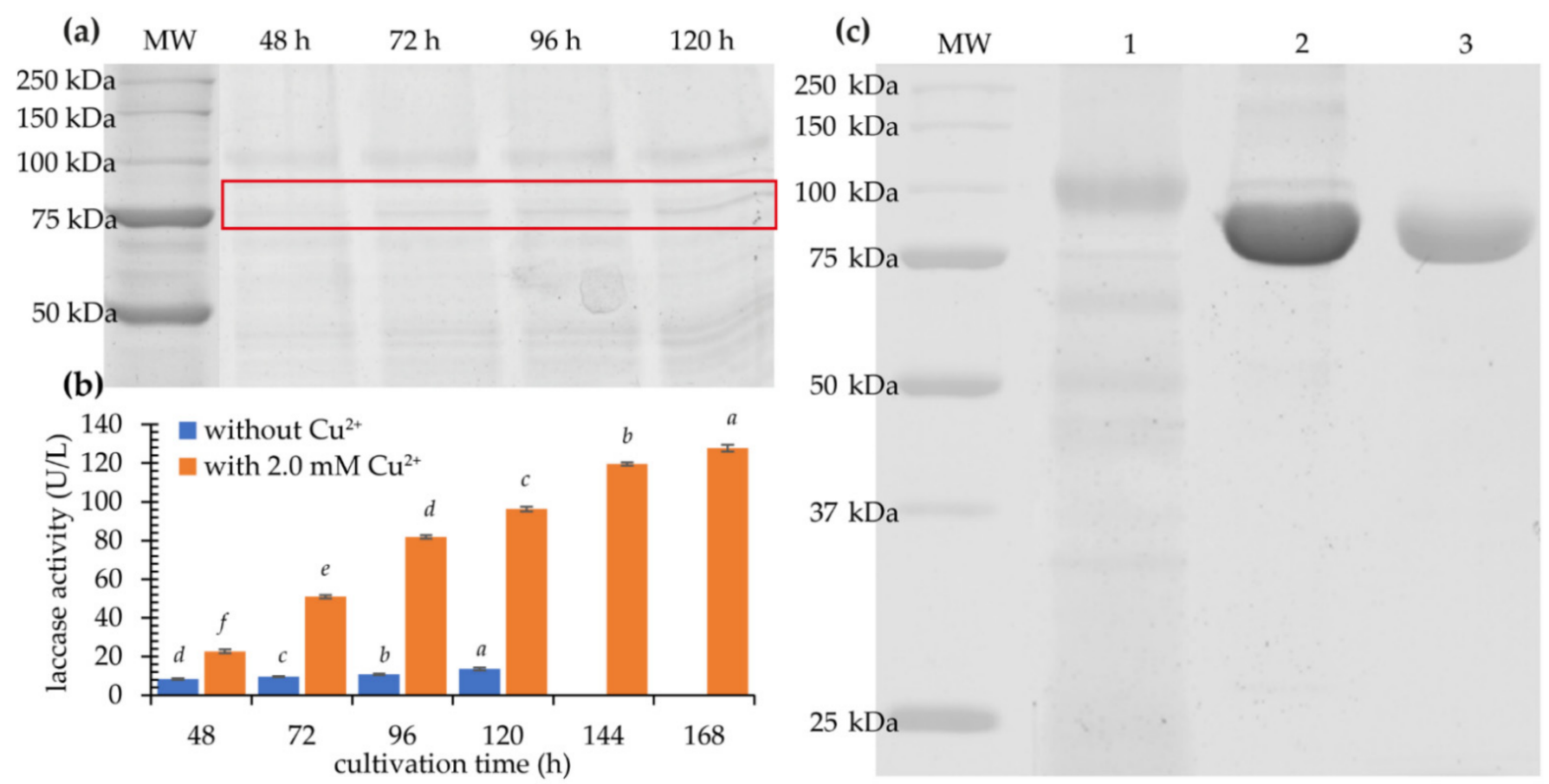

Figure 4. SDS-PAGE of the recombinant protein; (a) laccase KbLcc1 production after 48, 72, 96 and 120 h cultivation of P. pastoris in expression medium BMMY (without $\mathrm{Cu}^{2+}$ ); KbLcc1 laccase bands were indicated by the red frame; $(\mathbf{b})$ increase of laccase $\mathrm{KbLccl}$ activity during cultivation time in medium without and with copper supplementation $\left(2.0 \mathrm{mM} \mathrm{Cu}^{2+}\right)$; the data presented as the means \pm SD from at least three independent experiments; the means that are marked with different letters ( $a-d$ for data series without $\mathrm{Cu}^{2+}$ and $a-f$ for data series with $\left.2.0 \mathrm{mM} \mathrm{Cu}^{2+}\right)$ are significantly different $(p<0.05)$; (c) purification of KbLcc1, 1: ultrafiltrated crude post-culture supernatant after $168 \mathrm{~h}$ of expression with $2.0 \mathrm{mM} \mathrm{Cu}^{2+}$; 2: fraction after salting-out using ammonium sulfate; 3: purified KbLcc1; MW: molecular weight marker.

The best recombinant clone CI was chosen for the optimization of culture conditions. Various copper (II) ion concentrations $(0.5,1.0,1.5,2.0$, and $2.5 \mathrm{mM})$ were added to buffered complex methanol medium (BMMY) medium. Increase of the laccase activity was observed for $0.5-2.0 \mathrm{mM}$, whereas $2.5 \mathrm{mM}$ turned out to be too high (the laccase activity dropped to about 30 U/L after 7 days; Supplementary Figure S1). The highest enzymatic activity was noted after 7 days of the culture with $2.0 \mathrm{mM}$ of $\mathrm{Cu}^{2+}$, namely $127.7 \mathrm{U} / \mathrm{L}$, which was about 10 times higher than in medium without supplementation after 5 days $(13.6 \mathrm{U} / \mathrm{L})$ (Figure 4b). The reasons for the increased activity can be found in the fact that copper ions added to the substrate during heterologous laccase production ensure the correct folding of the enzyme [31]. The optimization of the concentration of copper ions in the medium also allowed for an increase in the efficiency of expression in the case of laccase Cplcc1 from Coriolopsis polyzona MUCL 38443. The addition of $0.8 \mathrm{mM} \mathrm{CuSO}_{4}$ increased the activity from $211.29 \mathrm{U} / \mathrm{L}$ to $380.52 \mathrm{U} / \mathrm{L}$. Moreover, further optimization, including the concentration of methanol and alanine in the medium and the temperature of the culture, increased the activity of heterologous laccase to a maximum value of $800 \mathrm{U} / \mathrm{L}$ [32]. In turn, Bao et al. [33] achieved the expression of laccase Lac1 from Coprinus comatus in $P$. pastoris at the level of activity of $550 \mathrm{U} / \mathrm{L}$ in a medium containing $0.5 \mathrm{mM} \mathrm{Cu}{ }^{2+}$ and $1 \%$ methanol [33]. The KbLcc1 laccase expression efficiency at the level of approximately 
$130 \mathrm{U} / \mathrm{L}$ is sufficient for the characterization of the enzyme and the search for areas of its application. However, the production yield of KbLcc1 could be further improved by optimization of the expression medium, culture conditions, and genetic engineering strategies, such as the usage of different promoters, secretory signal sequences, and codon optimization for the P. pastoris expression system.

\subsection{Purification of Recombinant Laccase}

Post-culture liquid after $168 \mathrm{~h}$ of culture of P. pastoris clone CI was centrifuged, concentrated, and purified to obtain a highly pure preparation of laccase KbLcc1. Thus, 48.94-fold purification was achieved, which correlated to a final enzyme yield of $29.39 \%$ (Table 2). The protein concentration after purification was $0.359 \mathrm{mg} / \mathrm{mL}$. Both the crude and purified enzyme were stored in a refrigerator at $4{ }^{\circ} \mathrm{C}$. Expression of the recombinant psychrophilic laccase $\mathrm{KbLcc} 1$ resulted in $40 \times$ higher enzymatic activity, from the level of $0.5 \mathrm{U} / \mathrm{mg}$ for native [29], to the level of $20.5 \mathrm{U} / \mathrm{mg}$ for the heterologously expressed protein. Similar values were achieved for the recombinant laccase LccA from Trametes versicolor $(28.8 \mathrm{U} / \mathrm{mg})$ [34]. In turn, the cold-adapted laccase from Colletotrichum lagenarium expressed in P. pastoris was characterized with lower specific activity of $5.33 \mathrm{U} / \mathrm{mg}$ [35].

Table 2. Summary of the purification procedure for laccase KbLcc1.

\begin{tabular}{cccccc}
\hline Purification Step & Total Activity (U) & Total Protein $(\mathbf{m g})$ & Specific Activity (U/mg) & Yield (\%) & Purification (fold) \\
\hline Crude extract & 125.15 & 298.90 & 0.419 & $100 \%$ & 1.00 \\
Ultrafiltration & 105.26 & 139.15 & 0.756 & $84.11 \%$ & 1.81 \\
Ammonium sulfate precipitation & 65.96 & 54.24 & 1.216 & $52.71 \%$ & 2.90 \\
Mono S columnion exchange & 36.78 & 1.795 & 20.49 & $29.39 \%$ & 48.94 \\
chromatography & & & & \\
\hline
\end{tabular}

The SDS-PAGE electrophoresis of the purified recombinant enzyme corroborated the high efficiency of the purification process, showing the expected protein band without clearly visible other ballast protein bands (Figure 4c). The recombinant enzyme had a molecular weight of $76 \mathrm{kDa}$ which is slightly higher than the theoretical mass of $69.6 \mathrm{kDa}$ probably due to glycosylation. Analysis of the KbLcc1 laccase coding sequence revealed the presence of four potential $\mathrm{N}$-glycosylation sites. The molecular mass of the purified laccase $\mathrm{KbLcc} 1(76 \mathrm{kDa})$ is typical for fungal laccases which may fall in the range of $50-140 \mathrm{kDa}$, although the most common enzymes range from 60 to $70 \mathrm{kDa}$ [36]. The content of sugar residues in laccase molecules most often varies between $10 \%$ and $25 \%$ and depends on the type of microorganism and the growth environment. For example, laccase of marine fungi Trematosphaeria mangrovei isolated from decayed wood samples collected from Abour Keer in Egypt is a glycoprotein with 23\% carbohydrate content and molecular weight of $48 \mathrm{kDa}$ [37]. The presence of sugar residues protects the enzyme against proteolysis and inactivation by radicals formed as a result of laccase action. Moreover, it also ensures laccase conformational stability [38]. Molecular masses of laccases from Aureobasidium pullulans strains NRRL-50381 and NRRLY-2568 were greater than 100 and $150 \mathrm{kDa}$, respectively. After endoglycosidase treatment, molecular weights were reduced to $60-70 \mathrm{kDa}$ for NRRL50381 and to over $100 \mathrm{kDa}$ for NRRLY-2568, but both enzymes lost $40-50 \%$ of original activity [39].

\subsection{Characterization of Purified KbLcc1 Laccase}

2.3.1. Influence of $\mathrm{pH}$ and Temperature on Purified Laccase KbLcc1 Activity and Stability

Optimal $\mathrm{pH}$ and temperature values were determined for the reactions with four substrates: ABTS, syringaldazine, guaiacol, and sinapic acid. Optimal $\mathrm{pH}$ was determined to be $3.5,7.0,5.5$, and 6.5 , for ABTS, syringaldazine, guaiacol, and sinapic acid, respectively (Figure 5a). The impact of $\mathrm{pH}$ on the stability of the laccase was investigated using ABTS as a substrate. The enzyme is stable for $24 \mathrm{~h}$ over a wide $\mathrm{pH}$ range, retaining more than $90 \%$ activity at $\mathrm{pH} 4.5-6.0$, and more than $80 \%$ at $\mathrm{pH} 3.5-8.5$ (Figure $5 \mathrm{~b}$ ). These values 
are similar to those observed for the native laccase G3 K. bupleuri [29], as well as to other fungal laccases. ABTS is the most popular substrate used in the study of laccase activity. The optimum $\mathrm{pH}$ values for such reactions are most often in the range of 3.0-4.0 [35,40], however, there are also laccases characterized by slightly higher optimal $\mathrm{pH}$ reaching the values of 5.0, e.g., for the laccase from A. pullulans [41] and Thielavia sp. [42], and $\mathrm{pH} 6.0$ for the laccase from Thermus thermophilus [43]. Optimal $\mathrm{pH}$ in the reaction with syringaldazine, sinapic acid and guaiacol are most often higher than for ABTS, but they remain within the acidic $\mathrm{pH}$ range. The process of oxidation of phenolic compounds depends on the difference in the redox potential between the reactant and the T1 copper atom in the enzyme's active site. As the $\mathrm{pH}$ increases due to the oxidative proton release, the $\mathrm{E}_{0}$ potential of the phenolic compounds decreases. The change in $\mathrm{E}_{0}$ in the case of phenol can even reach $490 \mathrm{mV}$ with an increase in $\mathrm{pH}$ from 2.7 to $\mathrm{pH} 11$. At the same time, for laccases, it is much smaller (approximately $100 \mathrm{mV}$ ). Moreover, an increase in $\mathrm{pH}$ causes $\mathrm{OH}^{-}$to bind to copper atoms T2/T3, which disrupts the electron transfer between $\mathrm{T} 1$ and $\mathrm{T} 2 / \mathrm{T} 3$ centers [44].
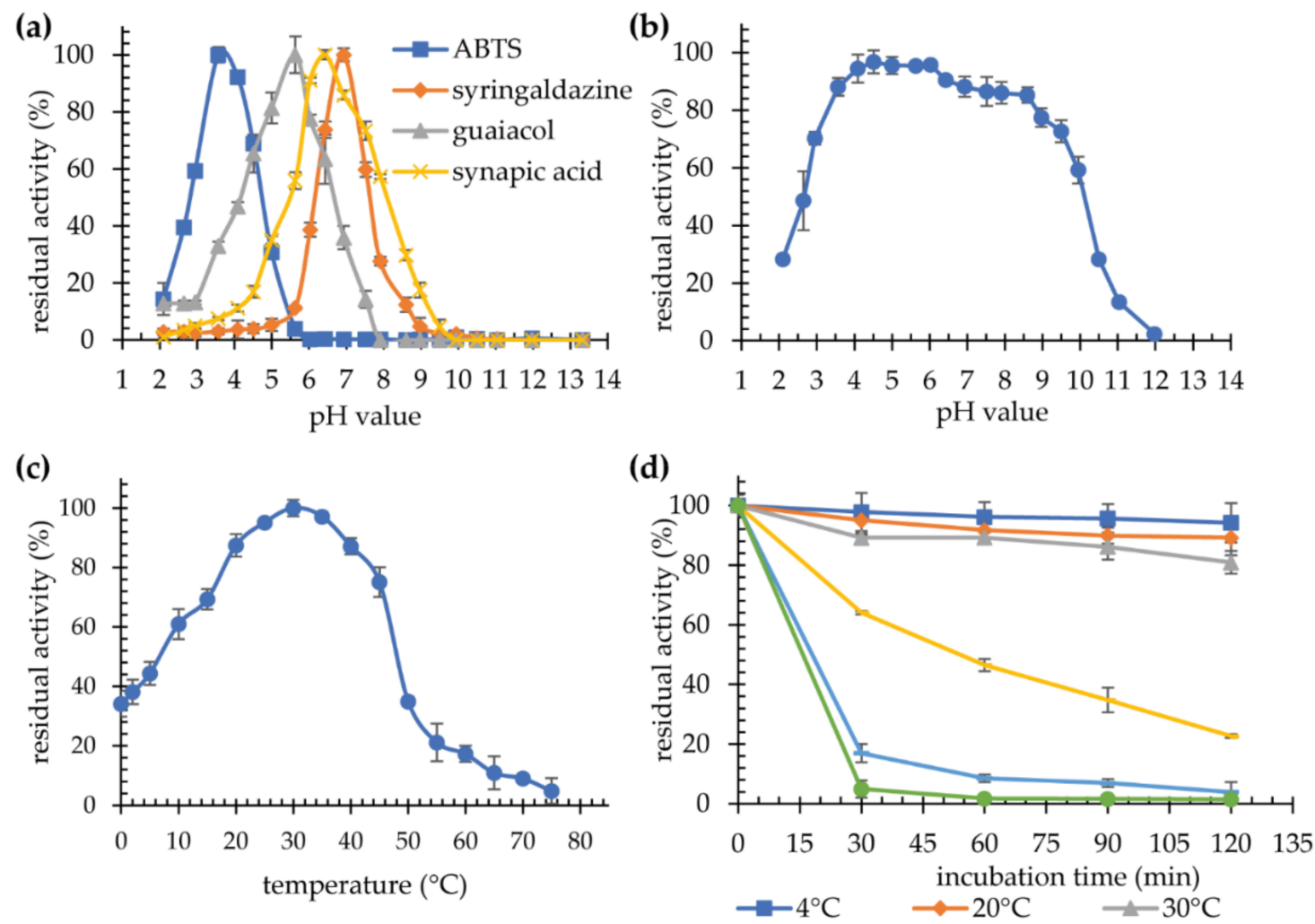

Figure 5. Characterization of purified recombinant laccase KbLcc1; (a) optimal pH in reaction with different substrates; (b) $\mathrm{pH}$-stability after 24-h incubation at $4{ }^{\circ} \mathrm{C}$ (with ABTS used as a substrate); (c) optimal temperature in reaction with ABTS as a substrate; (d) thermostability at $4{ }^{\circ} \mathrm{C}, 20^{\circ} \mathrm{C}, 30^{\circ} \mathrm{C}, 40^{\circ} \mathrm{C}, 45^{\circ} \mathrm{C}$ and $50{ }^{\circ} \mathrm{C}$; pH-stability and thermostability obtained with ABTS as a reaction substrate.

The highest activity of laccase KbLcc1 towards syringaldazine was noted at $\mathrm{pH}$ 7.0, which is similar to the laccase from Melanocarpus albomyces [45] and higher than for the laccase from Vovariella volvacea V14 (optimal pH 5.6) [46] or from Shiraia sp. SUPER-H168 (optimal pH 6.0) [47].

The highest activity with ABTS as a substrate was recorded at $30^{\circ} \mathrm{C}$ (Figure 5c). A rapid drop in laccase activity was observed above $45^{\circ} \mathrm{C}$. The enzyme was operating at low temperatures, $0-20{ }^{\circ} \mathrm{C}$, retaining $34-87 \%$ of the maximum activity. The same optimal temperature, i.e., $30^{\circ} \mathrm{C}$, was observed for all four substrates (Table 3, Supplementary Table S1), which was consistent with that reported for the native G3 laccase from K. bupleuri. Re- 
combinant laccase $\mathrm{KbLcc} 1$ is stable at temperatures of $4-30{ }^{\circ} \mathrm{C}$ for 120 min (Figure $5 \mathrm{~d}$ ). Higher temperature probably causes irreversible changes in the protein structure, gradually leading to its inactivation. The decrease in activity was observed after $30 \mathrm{~min}$ at $40{ }^{\circ} \mathrm{C}$ by almost $40 \%$, while after $120 \mathrm{~min}$ the enzyme retained only $20 \%$ of its initial activity. Moreover, the temperature of $50{ }^{\circ} \mathrm{C}$ almost completely inactivated the enzyme after $30 \mathrm{~min}$ of incubation (Figure 5d). The results obtained for the recombinant KbLcc1 laccase, i.e., high activity at low temperatures $\left(61 \%\right.$ and $34 \%$ of maximal activity at $10{ }^{\circ} \mathrm{C}$ and $0{ }^{\circ} \mathrm{C}$, respectively) and high thermolability, confirm the psychrophilic nature of the new enzyme.

Table 3. Kinetic parameters for purified recombinant laccase KbLcc1.

\begin{tabular}{|c|c|c|c|c|c|c|}
\hline Substrate & $\mathrm{T}_{\text {opt }}\left({ }^{\circ} \mathrm{C}\right)$ & $\mathrm{pH}_{\mathrm{opt}}$ & $\mathrm{K}_{\mathrm{M}}(\mathrm{mM})$ & $\mathrm{V}_{\max }\left(\mathrm{U} \mathrm{mg}^{-1}\right)$ & $\mathrm{k}_{\mathrm{cat}} *\left(\mathrm{~s}^{-1}\right)$ & $\mathrm{k}_{\mathrm{cat}} / \mathrm{K}_{\mathrm{M}}\left(\mathrm{mM}^{-1} \mathrm{~s}^{-1}\right)$ \\
\hline ABTS & 30 & 3.5 & 0.580 & 34.18 & 39.64 & 68.35 \\
\hline Syringaldazine & 30 & 7.0 & 0.021 & 33.03 & 38.31 & 1808.82 \\
\hline Guaiacol & 30 & 5.5 & 13.28 & 4.70 & 5.45 & 0.41 \\
\hline Sinapic acid & 30 & 6.5 & 0.015 & 1.39 & 1.61 & 109.26 \\
\hline
\end{tabular}

* The molecular weight of KbLcc1 was $69.6 \mathrm{kDa}$, which was used to calculate the $\mathrm{k}_{\mathrm{cat}}\left(\mathrm{s}^{-1}\right)$ values. All of the values were calculated by the linear regression (correlation coefficient $\geq 0.99$ ) of double reciprocal plots, $f(1 /[S])=1 /[\mathrm{v}]$, from every set of triplicate measurement $(\mathrm{SD}<5 \%)$ (Supplementary Materials, Tables S2-S5).

Most of the described laccases are stable at temperatures of $30-50{ }^{\circ} \mathrm{C}$, and they lose their activity above $60^{\circ} \mathrm{C}$. Despite the relevance of cold-adapted and psychrophilic laccases for industrial and environmental applications, studies related to these proteins are scarce. Laccase produced by Cryptococcus albidus (now Naganishia albida) was characterized by maximum activity in the temperature range of $20-30^{\circ} \mathrm{C}$ and high thermolability. Moreover, its half-life was $81 \mathrm{~min}$ at $25^{\circ} \mathrm{C}$ and $64 \mathrm{~min}$ at $45^{\circ} \mathrm{C}$ [48]. Laccase from T. mangrovei is an interesting example as well, because despite maximum activity at $65^{\circ} \mathrm{C}$, it loses $40 \%$ of activity already after $60 \mathrm{~min}$ at $40^{\circ} \mathrm{C}$, and $98 \%$ at $65^{\circ} \mathrm{C}$ [37]. Laccase Lac1326 derived from a marine metagenomic library can also be categorized as a cold-adapted enzyme. Maximum activity was noted for $60{ }^{\circ} \mathrm{C}$. However, it retained $26.5 \%$ activity at $0{ }^{\circ} \mathrm{C}$ and more than $40 \%$ at $10{ }^{\circ} \mathrm{C}$ [49]. Cold-adapted enzymes are used in organic syntheses carried out in mixed aqueous-organic or non-aqueous solvents. The inherent flexibility of psychrozymes counteracts the stabilizing effects of low water activity in organic solvents [50].

\subsubsection{Substrate Specificity}

Most laccases are characterized by a strong affinity and a high catalytic constant for ABTS and syringaldazine, while guaiacol oxidation is slower and the $K_{M}$ value is higher. Additionally, $\mathrm{K}_{\mathrm{M}}$ values are usually low for sinapic acid [44]. The reported recombinant laccase followed this trend (Table 3).

$\mathrm{K}_{\mathrm{M}}$ values for ABTS are usually between 0.1 and $3.7 \mathrm{mM}$ [44]. For laccases from Ganoderma lucidum expressed in P. pastoris, $\mathrm{K}_{\mathrm{M}}$ and $\mathrm{V}_{\max }$ values were $0.521 \mathrm{mM}$ and $19.65 \mathrm{U} / \mathrm{mg}$, respectively, [51] which is very similar to the enzyme from this study. Laccase KbLcc1 displayed a strong affinity to syringaldazine $\left(\mathrm{K}_{\mathrm{M}}=0.021 \mathrm{mM}, \mathrm{k}_{\text {cat }}=38.31 \mathrm{~s}^{-1}\right)$, with subsequent low affinity to guaiacol $\left(\mathrm{K}_{\mathrm{M}}=13.28 \mathrm{mM}, \mathrm{k}_{\mathrm{cat}}=5.45 \mathrm{~s}^{-1}\right)$. The highest $\mathrm{V}_{\max }$ was noted for ABTS, i.e., $34.18 \mathrm{U} / \mathrm{mg}$ (Table 3). Similar affinity to syringaldazine was reported for the enzyme from Th. thermophilus $\left(\mathrm{K}_{\mathrm{M}}=0.017 \mathrm{mM}, \mathrm{k}_{\mathrm{cat}}=10.3 \mathrm{~s}^{-1}\right)$ [43]. An et al. [52] described the laccase produced by Postia placenta MAD-698-R, which was not active towards syringaldazine, but rather towards ABTS $\left(\mathrm{K}_{\mathrm{M}}=0.022 \mathrm{mM}, \mathrm{k}_{\mathrm{cat}}=1213 \mathrm{~s}^{-1}\right)$ [52]. The broad substrate specificity indicates a high potential for the use of KbLcc1 laccase in organic synthesis, dye decolorization, and bioremediation.

\subsubsection{Influence of Ions on Laccase KbLcc1 Activity}

The influence of metal ions on enzyme activity is extremely important in the context of industrial applications. As a result of their presence, catalytic proteins can be both activated and inhibited, which in turn determines the positive course of the process or the absence of the enzyme's action. 
The influence of various cations on the activity of purified laccase in the ABTS oxidation reaction as well as the stability of the enzyme during 24-h and 10-day incubations in the presence of selected ions was investigated. Incubation was carried out at $4{ }^{\circ} \mathrm{C}$. Thereby, $\mathrm{Ni}^{2+}, \mathrm{Cu}^{2+}, \mathrm{Mn}^{2+}$, and $\mathrm{Zn}^{2+}$ ions at the concentration of $1 \mathrm{mM}$, as well as $\mathrm{Co}^{2+}, \mathrm{Ca}^{2+}$, and $\mathrm{Mg}^{2+}$ ions at $2 \mathrm{mM}$ did not have any significant impact on the activity of laccase KbLcc1. Moreover, for these ions at $5 \mathrm{mM}$ concentration, the activity of at least approximately $80 \%$ of the maximum was still observed. For higher concentrations, a gradual decrease in activity was observed, up to approximately $60 \%$ in the presence of $10 \mathrm{mM} \mathrm{Co}{ }^{2+}$. Only iron ions were found to have a strong negative effect on enzyme activity as $1 \mathrm{mM} \mathrm{Fe}{ }^{2+}$ and $2 \mathrm{mM} \mathrm{Fe}^{3+}$ completely inhibited enzyme's action (Figure 6).
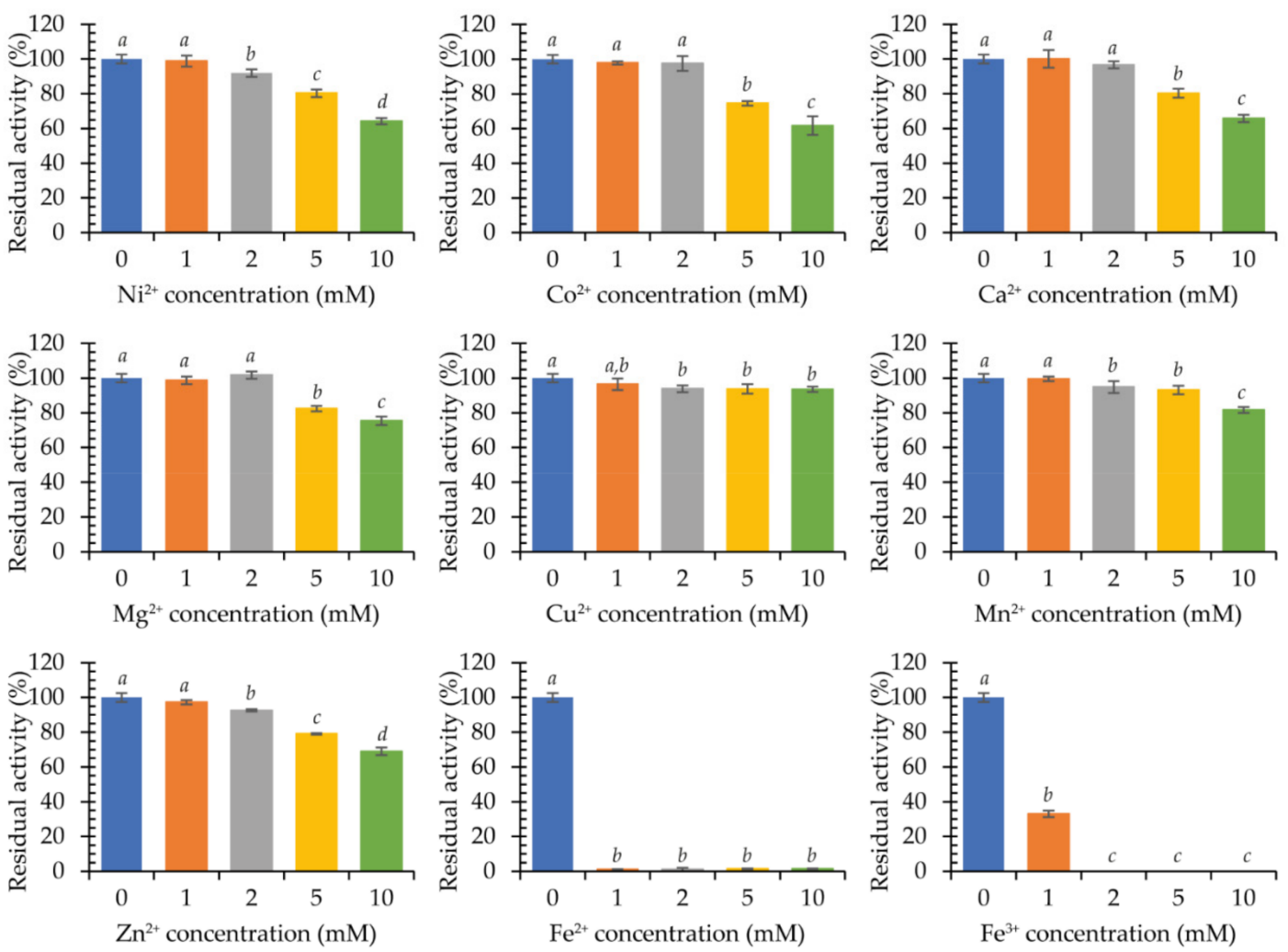

Figure 6. Activity of purified recombinant laccase KbLcc1 in the presence of various metal ions at $1 \mathrm{mM}, 2 \mathrm{mM}, 5 \mathrm{mM}$ and $10 \mathrm{mM}$ concentration in the reaction mixture; the data presented as the means \pm SD from at least three independent experiments; the means that are marked with different letters $(a-d)$ are significantly different $(p<0.05)$.

After 24-h incubation, a clear decrease in laccase activity was observed in the presence of cations $\mathrm{Fe}^{2+}$ and $\mathrm{Fe}^{3+}$ (Figure 7 ). Indeed, a $1 \mathrm{mM}$ concentration resulted in a loss of 70.1\% and $89.3 \%$ of activity, respectively. Higher concentrations almost completely inactivated the enzyme. $\mathrm{Ni}^{2+}$ ions at $1 \mathrm{mM}$ caused a minor $8.2 \%$ enzyme's activation, whereas $\mathrm{Cu}^{2+}$ ions lead to approximately $7 \%$ drop at the concentrations of 1 and $2 \mathrm{mM}$, similarly to $5 \mathrm{mM}$ $\mathrm{Co}^{2+}$. In the case of $\mathrm{Mn}^{2+}$ and $\mathrm{Zn}^{2+}$ ions, a significant negative effect was observed only for $2 \mathrm{mM}$, whereas $\mathrm{Ca}^{2+}$ and $\mathrm{Mg}^{2+}$ ions did not have any impact on the stability of $\mathrm{KbLcc1}$ laccase. Larger differences were found after 10-days incubation (Supplementary Figure S2). In the samples containing $5 \mathrm{mM} \mathrm{Ca}^{2+}$ and 2 and $5 \mathrm{mM} \mathrm{Mg}^{2+}$, a significant increase in activity was observed, by $8.8 \%, 11.2 \%$, and $10.1 \%$, respectively. It was found that these ions have a beneficial effect on the stability of the tested laccase, which can be used during several days of enzymatic reactions, as well as for longer storage. The prolonged incubation confirmed a slight negative effect of the presence of manganese ions (a decrease in activity by approximately $9 \%$ at concentrations of 1 and $2 \mathrm{mM}$ ) and a more pronounced impact in the case of copper and zinc ions, which reduced the activity by approximately $20 \%$ in 
the tested concentrations. The influence of nickel and cobalt ions also turned out to be negative at 1,2 , and $5 \mathrm{mM}$, as nickel ions decreased laccase activity by $8.7 \%, 20.1 \%$, and $27.9 \%$, respectively, and cobalt ions by $4.3 \%, 16.6 \%$, and $37.4 \%$, respectively.
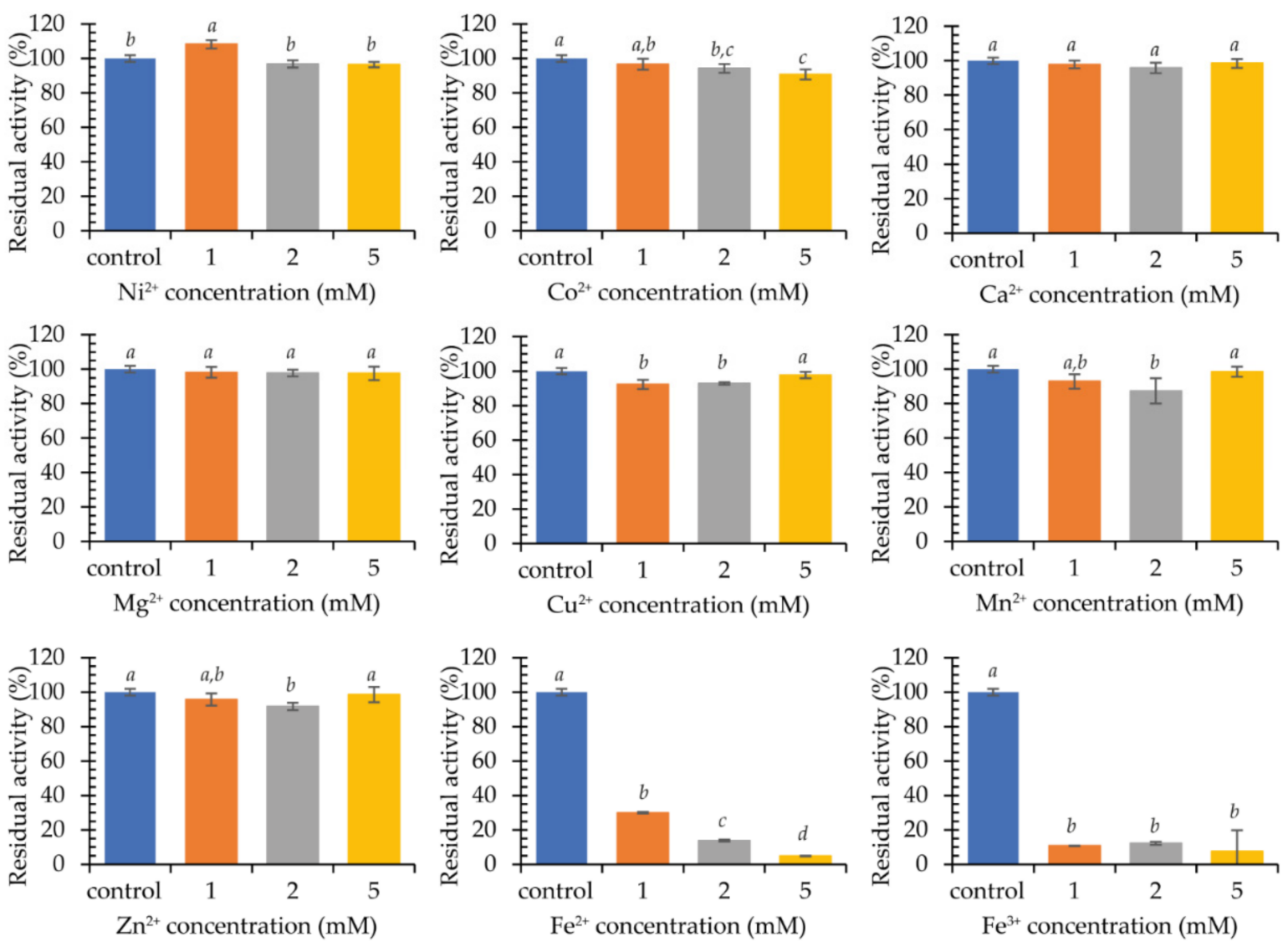

Figure 7. Stability of purified recombinant laccase KbLcc1 activity after $24 \mathrm{~h}$ of pre-incubation in the presence of various metal ions; the data presented as the means \pm SD from at least three independent experiments; the means that are marked with different letters $(a-d)$ are significantly different $(p<0.05)$.

The presence of metal ions influences the activity of laccases, both by inducing and reducing it. Metal ions such as copper, calcium, nickel, cobalt, and manganese, as a rule, have a noticeably inducing effect on the enzyme activity [53]. In the case of KbLcc1 laccase, such an effect was observed for $\mathrm{Ni}^{2+}$ ions at the concentration of $1 \mathrm{mM}$ during the $24-\mathrm{h}$ incubation and for all tested $\mathrm{Ca}^{2+}$ concentrations, when the incubation time was extended to 10 days. The enzyme produced by Schizophyllum commune NI-07 retained the activity in the presence of $0.1 \mathrm{mM} \mathrm{Cu}^{2+}$ (after 10 min incubation with metal ions followed by activity assay), and the other tested ions had a negative impact for the laccase even at $0.01 \mathrm{mM} \mathrm{[54].}$ Laccase from T. mangrovei retained approximately $60 \%$ activity in the presence of $\mathrm{Co}^{2+}$ and $\mathrm{Mg}^{2+}$ ions and approximately $70 \%$ in the presence of $\mathrm{K}^{+}$and $\mathrm{Na}^{+}$ions during $15 \mathrm{~min}$ incubation, whereas ions $\mathrm{Ca}^{2+}$ and $\mathrm{Mn}^{2+}$ had very little impact on the activity. In turn, $\mathrm{Fe}^{2+}$ ions at $1 \mathrm{mM}$ completely inactivated the enzyme [37]. Laccase produced by fungi Scytalidium thermophilum retained its activity in the presence of $10 \mathrm{mM} \mathrm{Cu}^{2+}, \mathrm{Mg}^{2+}, \mathrm{Zn}^{2+}$, $\mathrm{Ni}^{2+}, \mathrm{Co}^{2+}, \mathrm{Ca}^{2+}$, and $\mathrm{Mn}^{2+}$ ions, whereas $\mathrm{Fe}^{2+}$ ions inhibited the enzyme by $98 \%$ [55]. The negative effect of iron ions, especially $\mathrm{Fe}^{2+}$, on the activity of both KbLcc1 laccase and others, is probably due to the fact that they can disrupt the electron transport system in laccase, resulting in inhibition of the enzyme [56]. 


\subsubsection{Influence of Organic Solvents on Laccase KbLcc1 Activity}

Multicopper oxidases are used in the reactions of organic syntheses. For this reason, the influence of the presence of organic solvents in the reaction environment on the activity of the new psychrophilic laccase KbLcc1 was investigated. Acetone, ethyl acetate, methanol, ethanol, isopropanol, and hexane at concentrations of $1 \%, 10 \%, 20 \%$, and $40 \%(v / v)$ were selected for the experiment (Figure 8). In addition, the stability was analyzed by $24-\mathrm{h}$ incubation of the enzyme with the tested solvents at $4{ }^{\circ} \mathrm{C}$, followed by the ABTS oxidation reaction under the optimal conditions (Figure 9).
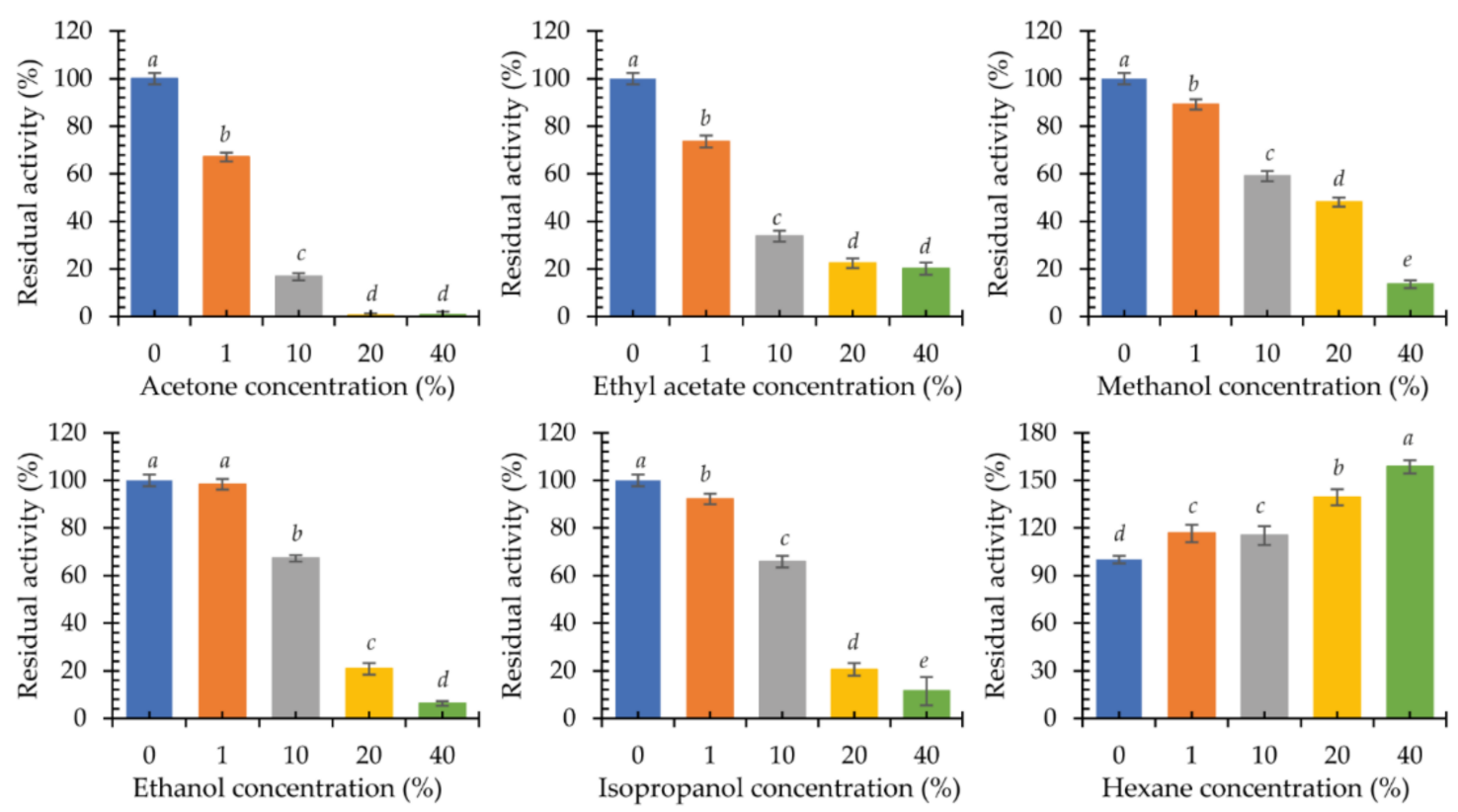

Figure 8. Activity of purified recombinant laccase KbLcc1 in the presence of organic solvents at $0 \%, 1 \%, 10 \%, 20 \%, 40 \%$ $(v / v)$ concentration; the data presented as the means \pm SD from at least three independent experiments; the means that are marked with different letters $(a-e)$ are significantly different $(p<0.05)$.
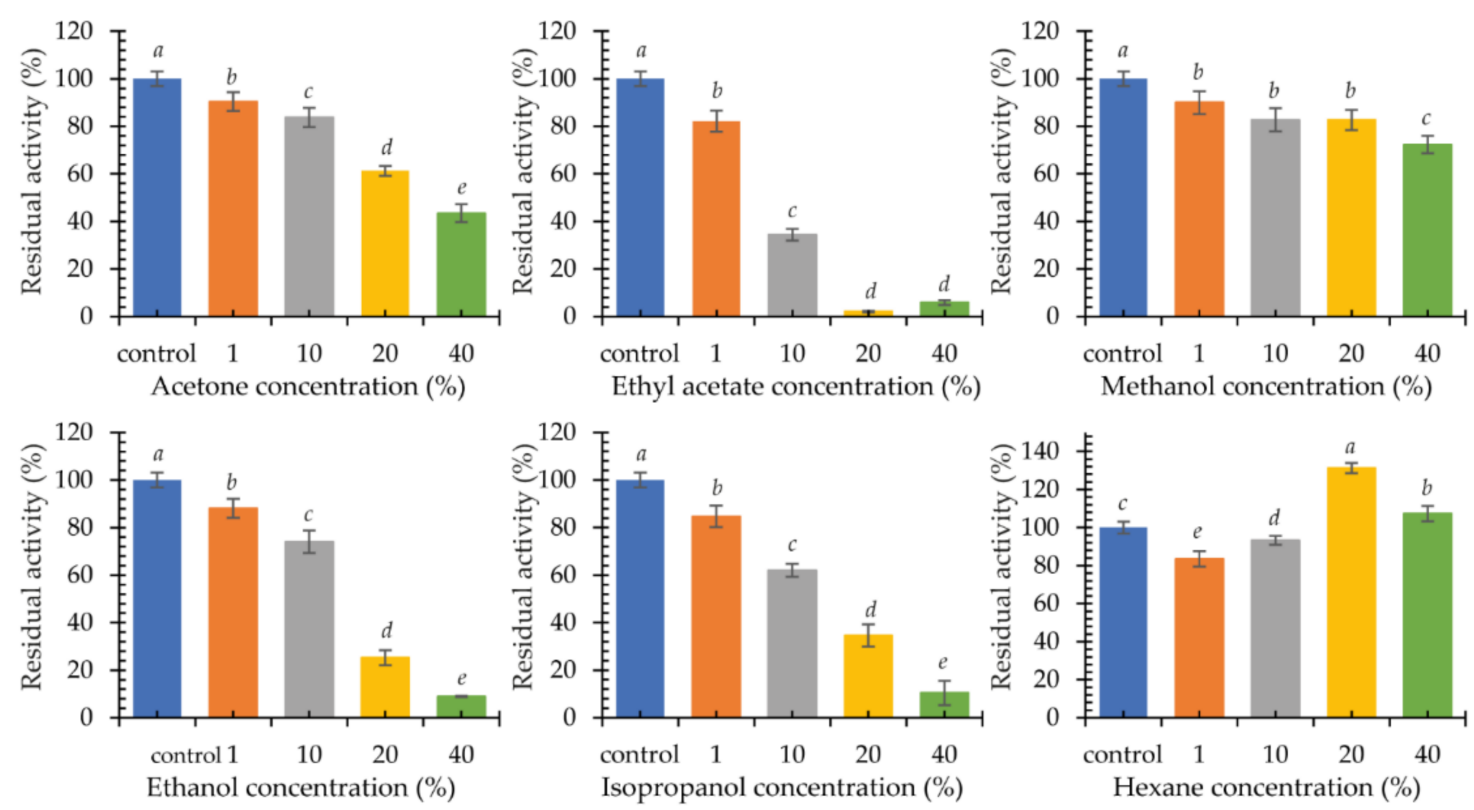

Figure 9. Stability of purified recombinant laccase KbLcc1 activity after 24 -h pre-incubation with organic solvents at $1 \%$, $10 \%, 20 \%$ and $40 \%(\mathrm{v} / \mathrm{v})$ concentration; the data presented as the means \pm SD from at least three independent experiments; the means that are marked with different letters $(a-e)$ are significantly different $(p<0.05)$. 
The presence of $1 \%(v / v)$ ethanol in the reaction mixture did not affect the performance of the purified KbLcc1 laccase. A slight negative effect was observed for $1 \%(v / v)$ methanol and $1 \%(v / v)$ isopropanol (approximately $90 \%$ of maximum activity), and a greater effect for $1 \%(v / v)$ acetone and $1 \%(v / v)$ ethyl acetate (approximately $70 \%$ of maximum activity). A further increase of the acetone concentration resulted in over $80 \%$ inactivation of the enzyme. For methanol, ethanol, and isopropanol, a similar effect was observed only at $40 \%$ $(v / v)$ concentration, while in the presence of $40 \%(v / v)$ ethyl acetate, laccase maintained approximately $20 \%$ of its maximum activity. The addition of hexane to the reaction mixture had a positive effect on the oxidation of ABTS by laccase KbLcc1. Hence, $1 \%(v / v)$ hexane caused a $16 \%$ increase in activity, while the greatest positive effect was observed for $40 \%$ $(v / v)$ hexane (an increase in activity by $58 \%$ ).

In the case of testing the enzyme stability in organic solvents, it was observed that preincubation in the presence of $1 \%(v / v)$ of the tested solvents had little effect on the stability of laccase (over $80 \%$ of residual activity), but a concentration increase in most cases had a strong negative effect. Ethyl acetate caused a loss of activity by $65 \%$ already at $10 \%(v / v)$ of the additive, and in the case of $20 \%(v / v)$ it completely inactivated the enzyme. The effect of pre-incubation with methanol was not so unfavorable, as at $40 \%(v / v)$ concentration the laccase retained $72 \%$ activity in relation to the control sample. The negative effect of acetone and ethanol was also observed for enzymes from Pycnoporus sanguineus CS43. For the two laccases LacI and LacII, there was a loss of 50\% activity in the presence of $47 \%$ and $31 \%$ $(v / v)$ acetone and 55\% and 52\% $(v / v)$ ethanol, respectively [57]. The presence of ethanol, methanol, and hexane in a concentration of $20 \%(v / v)$ did not affect the activity of archaean laccase from Halopiger aswanensis strain ABC_IITR. Increasing the hexane concentration to $40 \%(v / v)$ resulted in a rise in activity by $23 \%$. Acetone had a positive effect on the enzyme, causing a $28 \%$ and $45 \%$ increase in activity at concentration of $20 \%$ and $40 \%(v / v)$, respectively [58]. On the other hand, for TpL laccase from Trametes polyzonia WRF03, a slight negative effect of polar solvents at a concentration of $10 \%(v / v)$ was found, similarly to KbLcc1 laccase, while $50 \%(v / v)$ solvent addition resulted in a loss of almost $85 \%$ of activity in the case of ethanol, 55\% for methanol, and 50\% for acetone after $1 \mathrm{~h}$ of incubation [59]. Yang et al. [49] obtained opposite results for the laccase-like enzyme Lac1326 from a marine metagenomic library after 12-h incubation. Polar solvents, such as methanol, ethanol, and acetone at a concentration of $10 \%(v / v)$ favorably influenced the enzyme. There was a $60 \%, 70 \%$, and $137 \%$ increase in laccase activity, respectively [49]. Among the tested solvents, only hexane positively influenced the activity of the KbLcc1 enzyme, i.e., the $20 \%(v / v)$ concentration of the solvent resulted in a 30\% increase in activity, while at $40 \%$ $(v / v)$ hexane, a positive $7 \%$ effect was still observed. Depending on the nature of the organic solvent, its effect on the stability of laccase's catalytic hydrophobic core residues and ability to retain hydration properties may be different. Jafari et al. [60] investigated the effect of the presence of organic solvents on the hydration shell, structure, dynamics, interaction, and activity of laccases on the example of the laccase from T. versicolor. The enzyme in the presence of $50 \%(v / v)$ hexane retained a stable conformation (tertiary and secondary structures). On the other hand, 50\% $(v / v)$ ethanol caused changes in beta-turn and beta-sheet elements, negatively affecting the structure of laccase. Moreover, in the presence of hexane, the availability of substrate molecules to the active site increased, which increased the values of $\mathrm{V}_{\max }$ and $\mathrm{k}_{\text {cat }}$ in comparison to the reaction conducted in water or $50 \%(v / v)$ ethanol (decreased $V_{\max }$ and $\mathrm{k}_{\text {cat }}$ values). One possible explanation comes from the fact that polar solvents with $\log \mathrm{P}$ value smaller than 2 (i.e., ethanol) may remove the essential water molecules from the hydration shell of the enzyme, which is crucial for retaining its activity [60].

\subsection{Application of the Recombinant Laccase from K. bupleuri}

\subsubsection{Decolorization of Synthetic Dyes}

Our previous research has shown the possibility of effective use of the native G3 laccase from K. bupleuri in the decolorization of dyes such as methylene blue, alkaline 
fuchsin, Coomasie Brilliant Blue R-250 and crystal violet. The highest efficiency was found for crystal violet, i.e., about $40 \%$ for $1 \mathrm{~h}$ at $30{ }^{\circ} \mathrm{C}$ [29].

Heterologous expression of the gene encoding the KbLcc1 laccase and purification of the protein allowed to obtain an enzyme with a higher specific activity than the native one, and, at the same time, remarkably similar in terms of optimal reaction conditions $(\mathrm{pH}$, temperature) and stability ( $\mathrm{pH}$-stability, thermostability). The process of decolorization of methylene blue and alkaline fuchsin with the use of recombinant protein turned out to be more efficient (Table 4). In the cases of crystal violet and Coomassie Brilliant blue, there were no significant differences between the native and recombinant laccase. This study confirmed that laccase KbLcc1 from K. bupleuri could be a useful biocatalyst for the treatment of dye-containing effluents. Similar results were observed for the laccase from Phanerochaete flavido-alba. The recombinant enzyme was characterized by $5 \times$ higher specific activity than the native protein. The decolorization reaction of the synthetic dye Remazol brilliant blue R (RBBR) was similar for both variants of laccase. In the case of the dye Acid red 299, the process was much faster for the recombinant enzyme. After $40 \mathrm{~min}$ of incubation, over $30 \%$ decolorization was observed, with only $13 \%$ decolorization for the native laccase. After $100 \mathrm{~min}$, the differences were not so large, approximately $60 \%$ and $50 \%$ of the dye was removed, respectively, using recombinant and native enzyme [61]. In turn, the native laccase from P. sanguineus decolorized the synthetic RBBR dye in $94 \%$ within $2 \mathrm{~h} \mathrm{[62],} \mathrm{whereas} \mathrm{for} \mathrm{the} \mathrm{recombinant} \mathrm{enzyme,} 90 \%$ of decolorization was achieved [63].

Table 4. Decolorization of the synthetic dyes using native laccase G3 [29] and purified recombinant laccase KbLcc1 from Kabatiella bupleuri G3 IBMiP expressed in Pichia pastoris; reaction mixture contained $0.1 \mathrm{U}$ of laccase, $250 \mathrm{mg} / \mathrm{L}$ of synthetic dye and $1 \mathrm{mM}$ of ABTS as a redox mediator; the data presented as the means \pm SD from at least three independent experiments; the means that are marked with different letters $(a-b)$ are significantly different $(p<0.05)$.

\begin{tabular}{|c|c|c|c|c|}
\hline \multirow{2}{*}{ Dye } & \multirow{2}{*}{ Group } & \multirow{2}{*}{ Chemical Structure } & \multicolumn{2}{|c|}{$\%$ Decolorization } \\
\hline & & & Native & Recombinant \\
\hline Methylene blue & Heterocyclic/thiazine dye & & $18.2 \pm 2.5 \%^{b}$ & $23.8 \pm 1.2 \%^{a}$ \\
\hline Alkaline fuchsin & $\begin{array}{l}\text { Triphenylmethane dye and } \\
\text { aniline dye }\end{array}$ & & $31.7 \pm 3.3 \%{ }^{b}$ & $36.6 \pm 1.8 \%^{a}$ \\
\hline Crystal violet & Triphenylmethane dye & & $40.4 \pm 7.0 \%^{a}$ & $48.1 \pm 4.3 \%^{a}$ \\
\hline $\begin{array}{l}\text { Coomassie Brilliant } \\
\text { Blue R-250 }\end{array}$ & Triphenylmethane dye & & $19.8 \pm 5.8 \%^{a}$ & $24.4 \pm 3.9 \%$ \\
\hline
\end{tabular}

\subsubsection{Biotransformation of Ferulic Acid into Vanillin}

In the first stage of the research, the influence of temperature and ferulic acid concentration on the process of obtaining vanillin was determined. Reactions were performed at pH 7.0 at $20^{\circ} \mathrm{C}$ and $30^{\circ} \mathrm{C}$, with $1.0 \mathrm{mM}$ and $10.0 \mathrm{mM}$ ferulic acid concentrations. The expected product was found to be present in all tested samples after 5 days. A higher concentration of vanillin was observed when the reaction was carried out at $20^{\circ} \mathrm{C}$. Indeed, it was over $3 \times$ higher than in the reaction at $30^{\circ} \mathrm{C}$ (Table 5). The use of more starting material obviously gave rise to more product generation, but the increase is not as great as expected. The yield of the reaction to convert ferulic acid to vanillin is higher when $1 \mathrm{mM}$ substrate is used. 
Table 5. Vanillin concentration and molar yield of transformation ferulic acid by purified KbLcc1 laccase (0.1 U) without the redox mediator.

\begin{tabular}{ccccc}
\hline \multirow{2}{*}{ Ferulic Acid (mM) } & \multicolumn{2}{c}{$2{ }^{\circ} \mathbf{C}$} & \multicolumn{2}{c}{$\mathbf{3 0}{ }^{\circ}$} \\
\cline { 2 - 5 } & Vanillin (mg/L) & Molar Yield (\%) & Vanillin (mg/L) & Molar Yield (\%) \\
\hline 1.0 & 0.136 & 0.089 & 0.082 & 0.054 \\
10.0 & 0.291 & 0.019 & 0.119 & 0.008 \\
\hline
\end{tabular}

In the next stage of the research, the effect of the redox mediator's addition was evaluated. The reaction was carried out at $20^{\circ} \mathrm{C}$, using $1 \mathrm{mM}$ ferulic acid as a substrate at $\mathrm{pH} 7.0$ and at $\mathrm{pH} 3.5$, which is optimal for the oxidation of ABTS that acted as a mediator of electron transfer. The concentration of vanillin was determined every $24 \mathrm{~h}$ for 5 days. In trials without a mediator, the concentration of vanillin reached the maximum concentration of $1 \mathrm{mg} / \mathrm{L}$. The addition of ABTS and the adjustment of the reaction $\mathrm{pH}$ to the mediator resulted in a significant increase in the reaction yield. The highest concentration of vanillin was observed after 96 and $120 \mathrm{~h}$ of reaction, at 19.6 and $21.9 \mathrm{mg} / \mathrm{L}$, respectively, with molar yields of $12.85 \%$ and $14.39 \%$, respectively (Figure 10 and Supplementary Figures S3-S7).

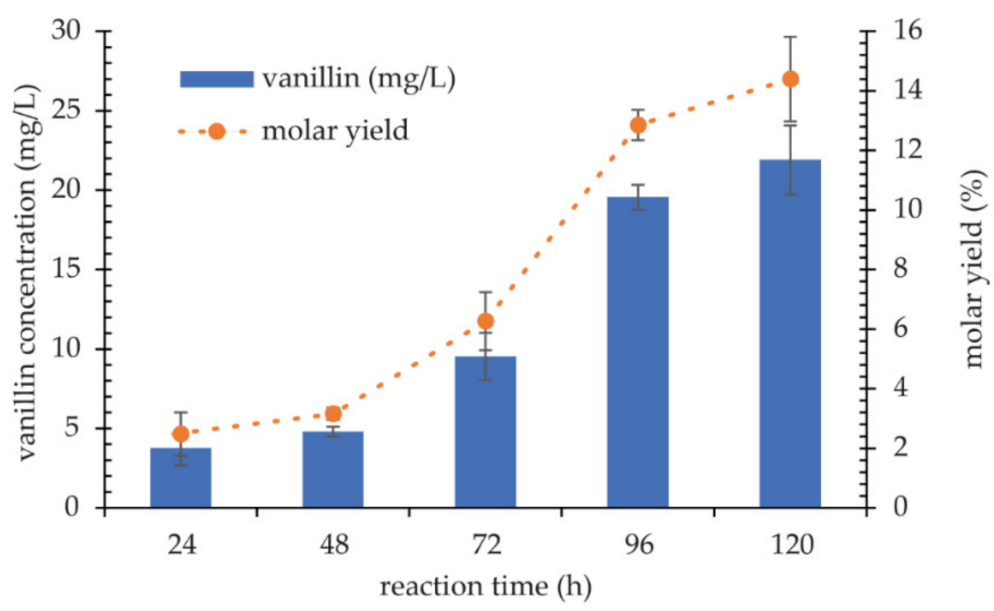

Figure 10. Transformation of the ferulic acid into vanillin by KbLcc1 laccase (0.1 U) with $1 \mathrm{mM}$ ABTS as a redox mediator at $20^{\circ} \mathrm{C}$ and $\mathrm{pH} 3.5$ (optimal for ABTS oxidation).

Vanillin is the main flavor compound in vanilla extract and probability the most popular universally appreciated global flavor. Concentration of vanillin in vanilla pod reaches $2.5-4.5 \%$ of dry mass. Annual global production of vanilla pods, vanilla extract and vanillin is over $18,000,000 \mathrm{~kg}$. Concerning the high production costs of vanilla pods and isolation of vanillin, the industry focuses on the chemical synthesis and biosynthesis of the main flavor ingredient. Chemical synthesis of vanillin has a negative environmental impact due to the use of hazardous chemicals. Biochemical and biotechnological processes are based on the usage of microorganisms and enzymes for transforming a wide range of different substrates into vanillin [22]. The bioconversion of ferulic acid is one of the most investigated ways of obtaining the natural vanillin. Four major pathways of ferulic acid degradation can be distinguished with respect to the initial reaction, namely nonoxidative decarboxylation, side chain reduction, coenzyme-A-independent deacetylation, and coenzyme-A-dependent deacetylation [64]. However, Wellington [65] mentioned research with the use of $T$. versicolor in which ferulic acid was used as a model in a reaction for the oxidative decomposition of lignin by laccase [65]. P. cinnabarinus laccasecatalyzed reaction of oxidative decomposition of ferulic acid to vanillin was also described by Falconnier et al. [27]. The transformation process took place during the cultivation of the fungus in a medium containing ferulic acid and resulted with 27.5 molar yield of vanillin bioconversion. More detailed studies, in which the purified enzyme from 
P. cinnabarinus was used for the reaction, did not confirm the previously obtained results, as no formation of vanillin from ferulic acid was observed. The participation of laccase in the described process has not been confirmed, but other enzymes possibly involved in the metabolism of ferulic acid have been identified [27]. In turn, the laccase from Myceliophthora thermophila catalyzed the oxidation of ferulic acid in which dye compounds were obtained. Reaction conducted in biphasic hydro-organic system composed of ethyl acetate and sodium phosphate buffer resulted in intermediate stable yellow products which could be applied as food colorants. The authors suggested that they arose as a result of combining the ferulic acid radicals formed after the action of laccase [21]. The results described in this study, observed for the KbLcc1 laccase, are the first to demonstrate the ability of the laccaselike enzyme to produce vanillin from ferulic acid. The processes of such biotransformation described so far concern, inter alia, a coenzyme-independent decarboxylase/oxygenase two-stage process [28]. The first step involved a 2-h decarboxylation reaction of ferulic acid to 4-vinylguaiacol catalyzed by Fdc decarboxylase expressed by recombinant $E$. coli. In the second stage, the recombinant $E$. coli cells expressing oxygenase Cso2 oxidized 4 -vinylguaiacol to produce vanillin. The efficiency of the process reached $7.8 \mathrm{~g} / \mathrm{L}$ of vanillin with $69.3 \%$ molar yield [28]. Other methods were described by Perez-Rodriguez with coworkers [26] and Chen with coworkers [25]. In the first mentioned study vanillin production was conducted using bacteria Amycolatopsis sp. ATCC 39116. The maximal yield of product was $212.4 \mathrm{mg} / \mathrm{L}$ with only $7.37 \%$ molar yield after 10 days of fed-batch fermentation in mineral salts medium supplemented with vanillic acid. During the process, other phenolic compounds (vanillic acid, vanillyl alcohol, 4-vinylguaiacol, guaiacol, and protocatechuic acid) were also evaluated [26]. In the second study, vanillin was obtained using bacteria $B$. subtilis which was immobilized onto carbon fiber textiles (CFT) in a bioreactor. During fermentation $1.55 \mathrm{~g} / \mathrm{L}$ of ferulic acid was used as a sole carbon source for bacterial growth. After $20 \mathrm{~h}$, the vanillin molar yield was 56.59\% [25]. Another example is a study of Tang and Hassan [24], who evaluated the production of vanillin by a fungus A. niger I-1472. Ferulic acid, a substrate for biotransformation, was initially extracted from pineapple peel and pineapple crown leaves and then converted to $2.5-5.0 \mathrm{mg} / \mathrm{L}$ of vanillin with $6.3-8.9 \%$ molar yield. It is suggested that ferulic acid-CoA ligase and 4-hydroxycinnamoyl-CoA hydratases/lyase are involved in this process [24].

The new KbLcc1 laccase offers an interesting alternative to obtain vanillin from ferulic acid based on an environmentally friendly bioprocess. The use of a biocatalyst in the production of a value-added product allows for mild reaction conditions and does not generate an excessive amount of waste products. In addition, biotransformation using a single enzyme, K. bupleuri G3 IBMP laccase, as opposed to enzyme complexes catalyzing the reactions, are simpler to optimize and more economical. The psychrophilic nature of the enzyme which is efficiently produced at moderate temperatures and does not require heating of bioreactors, also has a significant impact on reducing the costs. It is worth noting that the high thermolability of cold-loving laccase facilitates its quick inactivation after the completed process, thus reducing the risk of the release of the active enzyme into the environment with sewage. Moreover, a single enzyme is easier to immobilize and thus increases the stability of the preparation and enables the biotransformation to be carried out several times using the same portion of the enzyme.

\section{Materials and Methods}

\subsection{Strains, Plasmids and Media}

K. bupleuri G3 IBMiP was found to be a new cold-adapted laccase producer [29]. The strain was cultured in the medium containing $10.0 \mathrm{~g} / \mathrm{L}$ yeast extract, $20.0 \mathrm{~g} / \mathrm{L}$ peptone, and $20.0 \mathrm{~g} / \mathrm{L}$ glucose for 3 days at $20^{\circ} \mathrm{C}$. The E. coli strain Top10 F' (ThermoFisher Scientific, Waltham, MA, USA) were grown in a Luria-Bertani medium (LB) at $37^{\circ} \mathrm{C}$. The E. coli transformants were grown in the LB medium with $100 \mu \mathrm{g} / \mathrm{mL}$ of ampicillin at $37^{\circ} \mathrm{C}$. pJET1.2/blunt Cloning Vector (ThermoFisher Scientific, Waltham, MA, USA) was used for splicing in vitro and subcloning of DNA fragments for sequencing. The vector pPINK $\alpha-\mathrm{HF}$ 
(Invitrogen, Carlsbad, CA, USA) was used for the expression in P. pastoris (PichiaPink ${ }^{\mathrm{TM}}$ strain 1). Selective medium (SM, in g/L: glucose, 20.0; yeast nitrogen base without amino acids, 6.7; yeast synthetic drop-out medium supplements without histidine, leucine, tryptophan and adenine, 1.39; bacteriological agar, 20.0; histidine, 0.076 ; leucine, 0.38 ; tryptophan, 0.076), buffered complex glycerol and methanol media (BMGY and BMMY, in g/L: yeast extract, 10.0; peptone, 20.0; potassium phosphate, $100 \mathrm{mM} \mathrm{pH}$ 6.0; yeast nitrogen base, 13.4; biotin, 0.004; glycerol, 10.0, or methanol, 5.0) and other media and protocols for P. pastoris were as described in the PichiaPink ${ }^{\mathrm{TM}}$ Expression Manual (Invitrogen, Carlsbad, CA, USA) unless otherwise stated.

\subsection{Cloning of Laccase Gene from K. bupleuri G3 IBMiP}

\subsubsection{Genome Sequencing}

The laccase-encoding gene was identified in the K. bupleuri G3 IBMiP genome sequence. Sequencing was performed in the Bioinformatics Laboratory at Bionanopark in Łódź, Poland. Libraries were prepared according to the NExter DNA protocol (Ilumina, San Diego, CA, USA) and pair-end sequenced on a MiSeq device (Ilumina, San Diego, CA, USA). The SPAdes programme (version 3.8.1) was used to assemble the obtained data into a genome sequence (http:/ / bioinf.spbau.ru/spades, accessed on 14 July 2016) [66].

\subsubsection{Bioinformatics Analysis of Laccase Gene}

Genes encoding for laccases were identified on the basis of annotations carried out using the programmes: Augustus (http://augustus.gobics.de/, accessed on 1 August 2016) and GeneMark (http:/ / exon.gatech.edu/GeneMark/, accessed on 15 July 2016). The search of the obtained sequences for domains characteristic of multicopper oxidases was performed using Pfam 31.0 database (http:/ / pfam.xfam.org/, accessed on 15 July 2016) and in the Blast Standalone programme against the CDD database (https:/ /blast.ncbi.nlm. nih.gov/Blast.cgi, accessed on 18 July 2016). Selected sequences encoding laccase-like proteins were analyzed for the presence of introns and the characteristics of the encoded protein (molecular weight, signal peptide, pI, etc.) using the tools available on the Expasy server (https:/ / www.expasy.org/, accessed on 18 August 2016).

\subsubsection{KbLcc1 Gene Amplification and Cloning}

The laccase gene KbLcc1 with the intron sequence was amplified using primers L1 LF/L1 LR (Table 6) with genomic DNA as the template and using a combined 2-step and 3-step touch-down PCR protocol (Table 7). The amplified product was purified using GeneMatrix Basic DNA Purification Kit (EURx, Gdansk, Poland) and cloned to pJET1.2/blunt Cloning Vector using CloneJET PCR Cloning Kit (ThermoFisher Scientific, Waltham, MA, USA).

Table 6. Primers used in PCR reactions.

\begin{tabular}{cc}
\hline Name of Primer & Sequence $\mathbf{( 5}^{\prime} \mathbf{3}^{\prime} \mathbf{)}$ \\
\hline L1 LF & ATGCATCTACAGAAGCTCAGTGGCCTCT \\
L1 LR & CTAAAGTCCACTGTCGATTGAGGCCAAGC \\
IntR & AAATCGTGACCGTGCAAATGGATGGGATGA \\
IntF & CATTTGCACGGTCACGATTTCTTCGTCCTC \\
L1 SF & ATGCATCTACAGAAGCTCAGTG \\
L1 SR & CTAAAGTCCACTGTCGATTTGAG \\
L1 StuIF & AGGCCTATGCATCTACAGAAGCTC \\
L1 FseIR & GGCCGGCCTAAAGTCCACT \\
5'AOX1 1 & GACTGGTTCCAATTGACAAGC \\
3'CYC1 & GCGTGAATGTAAGCGTGAC \\
\hline
\end{tabular}


Table 7. Combined 2-step and 3-step touch-down PCR protocol.

\begin{tabular}{cccc}
\hline Cycle Step & Temperature $\left({ }^{\circ} \mathbf{C}\right)$ & Time & Cycles \\
\hline Initial denaturation & 98 & $30 \mathrm{~s}$ & \\
\hline Denaturation & 98 & $10 \mathrm{~s}$ & 5 \\
\hline Annealing/Extension & 72 & $60 \mathrm{~s}$ & \\
\hline Extension & 72 & $5 \mathrm{~min}$ & \\
\hline Denaturation & 98 & $10 \mathrm{~s}$ & \\
\hline Annealing & $72(-1 /$ cycle $)$ & $30 \mathrm{~s}$ & \\
\hline Extention & 72 & $60 \mathrm{~s}$ & \\
\hline Final extension & 72 & $10 \mathrm{~min}$ & \\
\hline Cooling & 4 & hold &
\end{tabular}

\subsubsection{Splicing In Vitro of KbLcc1 Gene}

Coding sequence of laccase KbLcc1 was obtained using the OE-PCR method according to the protocol described by Heckman and Pease [30] and presented at Figure 2. First PCR reactions were performed using primers L1 LF/IntR to amplify exon 1 (product $\mathrm{AB}$ ) and IntF/L1 LR to amplify exon 2 (product CD), with the conditions presented in Table 7 and the plasmid pJET1.2 with cloned KbLcc1 gene sequence used as a template. Products AB and $\mathrm{CD}$ were extracted from the agarose gel using agarose-out protocol from the GeneMatrix Basic DNA Purification Kit (EURx, Gdansk, Poland) and then used as the templates for PCR with primers L1 SF/L1 SR (Table 6) to obtain product AD (coding sequence of KbLcc1 laccase). Reaction conditions of PCR steps included the initial denaturation at $98{ }^{\circ} \mathrm{C}$ for $30 \mathrm{~s} ; 25$ cycles at $98^{\circ} \mathrm{C}$ for $10 \mathrm{~s}$ denaturing, annealing at $64.5^{\circ} \mathrm{C}$ for $30 \mathrm{~s}$, and extension at $72{ }^{\circ} \mathrm{C}$ for $60 \mathrm{~s}$; a final extension of $72{ }^{\circ} \mathrm{C}$ for $10 \mathrm{~min}$ followed by maintenance at $4{ }^{\circ} \mathrm{C}$. Gel-purified product AD was cloned to pJET1.2/blunt Cloning Vector using CloneJET PCR Cloning Kit (ThermoFisher Scientific, Waltham, MA, USA) and the obtained vector was transformed into E. coli Top10 $\mathrm{F}^{\prime}$ and plated on LB medium with ampicillin $(100 \mu \mathrm{g} / \mathrm{mL})$.

\subsubsection{Cloning of KbLcc1 Coding Sequence to Expression Vector}

Plasmid pJET1.2 with KbLcc1 coding sequence was isolated using GeneMatrix Basic DNA Purification kit (EurX, Gdansk, Poland) and used as a template in PCR reaction to add StuI and FseI restriction sites at the beginning and the end of coding KbLcc1 sequence using primers L1 StuIF/L1 FseIR. Reaction conditions of PCR steps included the initial denaturation at $98^{\circ} \mathrm{C}$ for $30 \mathrm{~s} ; 25$ cycles at $98^{\circ} \mathrm{C}$ for $10 \mathrm{~s}$ denaturing, annealing at $65.9^{\circ} \mathrm{C}$ for $30 \mathrm{~s}$, and extension at $72{ }^{\circ} \mathrm{C}$ for $60 \mathrm{~s}$. A final extension of $72{ }^{\circ} \mathrm{C}$ for $10 \mathrm{~min}$ was followed by maintenance at $4{ }^{\circ} \mathrm{C}$. Purified product was cloned to pJET1.2/blunt Cloning Vector using CloneJET PCR Cloning Kit (ThermoFisher Scientific, Waltham, MA, USA) and the obtained vector was transformed into E. coli Top $10 \mathrm{~F}^{\prime}$ and plated on LB medium with ampicillin $(100 \mu \mathrm{g} / \mathrm{mL})$. Isolated and purified plasmid pJET1.2 with KbLcc1 coding sequence and plasmid pPINK $\alpha$-HF were digested by FastDigest StuI (NEB, Ipswich, MA, USA) and FastDigest FseI (NEB, Ipswich, MA, USA) for $30 \mathrm{~min}$ at $37^{\circ} \mathrm{C}$. Gel-purified pPINK $\alpha$-HF vector and KbLcc1 gene were ligated by Anza T4 DNA Ligase (Promega, Madison, WI, USA) at $22{ }^{\circ} \mathrm{C}$ for $1 \mathrm{~h}$, and the product was used for electroporation of E. coli Top10 $\mathrm{F}^{\prime}$ at $1.8 \mathrm{kV}$ with a $0.1-\mathrm{cm}$ cuvette according to the protocol attached to MicroPulser (Bio-Rad, Hercules, CA, USA). The obtained construct was subjected to multi-enzyme digestion and linearization to confirm the correct length.

\subsubsection{Expression of the KbLcc1 Laccase in P. pastoris}

The recombinant plasmid pPINK $\alpha$-HF containing laccase KbLcc1 sequence was linearized with FastDigest SpeI according to the manufacturer's instruction (NEB, Ipswich, MA, USA) and transformed into P. pastoris (PichiaPink ${ }^{\mathrm{TM}}$ strain 1) competent cells by 
electroporation (MicroPulser, Bio-Rad, Hercules, CA, USA) by 1 pulse at $2.0 \mathrm{kV}$ for $5 \mathrm{msec}$ with a $0.2-\mathrm{cm}$ cuvette. The transformants were screened on SM plates. Positive clones were identified by colony PCR with the primers $5^{\prime} \mathrm{AOX} 1 / 3^{\prime} \mathrm{CYC} 1$ (Table 6).

Twenty-three positive clones of P. pastoris bearing the KbLcc1 gene, and one "empty" clone without gene, were incubated in $60 \mathrm{~mL}$ of BGMY for $48 \mathrm{~h}\left(24^{\circ} \mathrm{C}, 225 \mathrm{rpm}\right)$. Cells were collected by centrifugation and resuspended in $6 \mathrm{~mL}$ of BMMY containing $4.0 \%(v / v$, final concentration) of methanol, which was added every $24 \mathrm{~h}$ to induce the expression of the target protein. Cultivation was conducted at $20^{\circ} \mathrm{C}$ for 5 days with shaking $(225 \mathrm{rpm})$. The supernatant was collected by centrifugation at $5000 \times g$ for $5 \mathrm{~min}$ at $4{ }^{\circ} \mathrm{C}$ every $24 \mathrm{~h}$ during incubation time, and laccase activity and protein concentration were determined. SDS-PAGE was performed in a $12 \%$ running gel, and proteins were stained with Coomassie Brilliant Blue R-250. KbLcc1 laccase production for characterization of the recombinant protein was conducted with clone CI of P. pastoris at the same conditions, but with $2 \mathrm{mM}$ $\mathrm{CuSO}_{4}$ and $0.5 \%$ methanol concentration in BMMY medium and in larger volume scale. Copper ions were added to sterile BMMY medium.

\subsubsection{Purification of Recombinant Laccase KbLcc1}

The supernatant from $1 \mathrm{~L}$ culture of the recombinant $P$. pastoris clone CI was harvested by centrifugation at $10,000 \mathrm{rpm}$ for $30 \mathrm{~min}$ at $4{ }^{\circ} \mathrm{C}$. The supernatant was concentrated by ultrafiltration using Sartorius Stedim system and the membrane with cut-off of $10 \mathrm{kDA}$ (Hydrosart, Sartorius, Göttingen, Germany). The recombinant enzyme was precipitated by ammonium sulfate fractionation. The precipitate was dissolved in $10 \mathrm{mM}$ sodium acetate buffer ( $\mathrm{pH}$ 5.5) and then dialyzed for $12 \mathrm{~h}$ against the same buffer. Next, concentrated and pre-purified protein solution was loaded onto MonoS cation exchange column (GE Healthcare, Chicago, IL, USA) connected to ÄKTA Purifier system. The bound protein was eluted by $\mathrm{NaCl}$ gradient in $10 \mathrm{mM}$ sodium acetate buffer ( $\mathrm{pH}$ 5.5). The flow rate was set to $1 \mathrm{~mL} / \mathrm{min}$.

\subsection{Characterization of Purified Recombinant Laccase KbLcc1}

\subsubsection{Effect of Temperature and $\mathrm{pH}$ on Laccase Activity and Stability}

The optimum temperature for laccase activity was determined by incubating the reaction mixture over a temperature range of $0-80^{\circ} \mathrm{C}$ at a $\mathrm{pH}$ optimal for substrates $(1 \mathrm{mM}$, $30 \mu \mathrm{M}, 2 \mathrm{mM}$ and $250 \mu \mathrm{M}$ concentration of ABTS, syringaldazine, guaiacol and sinapic was used). To investigate the thermostability of the enzyme, it was incubated at $5-80{ }^{\circ} \mathrm{C}$ for 0-120 min within a 30 min interval, followed by measuring the enzyme activity at pH 3.5 with $1 \mathrm{mM}$ ABTS as a substrate. The effect of $\mathrm{pH}$ on laccase activity for different substrates was determined in $10 \mathrm{mM}$ Britton-Robinson buffer at $\mathrm{pH}$ in the range of 2.0-13.5 used in the reaction mixture. To investigate the $\mathrm{pH}$ stability, the enzyme $(1.0 \mathrm{U})$ was incubated for $24 \mathrm{~h}$ at $4{ }^{\circ} \mathrm{C}$ in $10 \mathrm{mM}$ Britton-Robinson buffer at $\mathrm{pH}$ in the range of $2.0-12.0$ and then $0.1 \mathrm{U}$ of the enzyme after incubation was used to determine the relative activity of laccase. The activity was determined with ABTS as a substrate at the optimum temperature $\left(30{ }^{\circ} \mathrm{C}\right)$ and optimal $\mathrm{pH}$ from ABTS (3.5). All the reactions were performed in triplicate. All experiments were conducted with $0.1 \mathrm{U}$ of the purified recombinant laccase KbLcc1.

\subsubsection{Substrate Specificity of Recombinant Laccase}

Substrate specificity of laccase KbLcc1 from K. bupleuri was estimated using 4 substrates: $\operatorname{ABTS}\left(\varepsilon_{420}=3.6 \times 10^{4} \mathrm{M}^{-1} \mathrm{~cm}^{-1}\right.$; conc. $\left.0.2-4.0 \mathrm{mM}\right)$, syringaldazine $\left(\varepsilon_{526}=6.5 \times 10^{4} \mathrm{M}^{-1} \mathrm{~cm}^{-1}\right.$; conc. $\left.5.5-40.0 \mu \mathrm{M}\right)$, guaiacol $\left(\varepsilon_{526}=4.8 \times 10^{4} \mathrm{M}^{-1} \mathrm{~cm}^{-1}\right.$; conc. $2.5-20.0 \mathrm{mM})$ and sinapic acid $\left(\varepsilon_{312}=1.76 \times 10^{4} \mathrm{M}^{-1} \mathrm{~cm}^{-1}\right.$; conc. $\left.3.0-150 \mu \mathrm{M}\right)$. Firstly, the optimum $\mathrm{pH}$ for each substrate was established in $10 \mathrm{mM}$ Britton-Robinson buffer pH 2.0-10.0 and with $1 \mathrm{mM}, 30 \mu \mathrm{M}, 2 \mathrm{mM}$, and $250 \mu \mathrm{M}$ concentration of ABTS, syringaldazine, guaiacol and sinapic acid used as a substrate, respectively. Activity determination was carried out at $30^{\circ} \mathrm{C}$. Kinetic parameters, namely $\mathrm{K}_{\mathrm{M}}, \mathrm{V}_{\max }$, and $\mathrm{k}_{\mathrm{cat}}$, were determined using the Lineweaver-Burk plots. 
3.3.3. The Effects of Metal Cations and Chemicals on the Activity and Stability of the Laccase

The laccase activity was determined in the presence of various metal ions $\left(\mathrm{Mg}^{2+}, \mathrm{Ca}^{2+}\right.$, $\left.\mathrm{Ni}^{2+}, \mathrm{Co}^{2+}, \mathrm{Zn}^{2+}, \mathrm{Cu}^{2+}, \mathrm{Mn}^{2+}, \mathrm{Fe}^{2+}, \mathrm{Fe}^{3+}\right)$. The metal ions were added to the reaction mixture at $1 \mathrm{mM}, 2 \mathrm{mM}, 5 \mathrm{mM}$, or $10 \mathrm{mM}$ concentration. Laccase activity was assayed with ABTS as a substrate under standard conditions described below. The stability of laccase in the presence of the same metal ions was studied by preincubating the buffered enzyme for $24 \mathrm{~h}$ and 10 days at $4{ }^{\circ} \mathrm{C}$ followed by enzyme activity assay. The metal ions were added to the enzyme in acetate buffer $(100 \mathrm{mM}, \mathrm{pH} 3.5)$ to a final concentration of 1.0, 2.0, and 5.0 mM. After incubation, samples were diluted to minimize the concentration of metal ions in the reaction mixture. A control sample preincubated without the metal ions was also performed. All assays were carried out in triplicate with $0.1 \mathrm{U}$ of the purified recombinant laccase KbLcc1.

The laccase activity was determined in the presence of various organic solvents (acetone, ethyl acetate, methanol, ethanol, isopropanol, hexane). The organic solvents were added to the reaction mixture at $1 \%, 10 \%, 20 \%$, and $40 \%(v / v)$ concentrations. Laccase activity was assayed with ABTS as a substrate under standard conditions described below. The stability of laccase in the presence of the same organic solvents were studied by preincubating the enzyme at $4{ }^{\circ} \mathrm{C}$ for $24 \mathrm{~h}$ followed by enzyme activity assay. The organic solvents were added to the enzyme in acetate buffer (100 mM, pH 3.5) to a final concentration of $1 \%, 10 \%, 20 \%$, and $40 \%(v / v)$. After incubation, samples were diluted with buffer to minimize the concentration of organic solvents in the reaction mixture. A control sample preincubated without organic solvent was also performed. All assays were carried out in triplicate with $0.1 \mathrm{U}$ of the purified recombinant laccase KbLcc1.

\subsection{Application of Laccase KbLcc1}

3.4.1. Decolorization of Synthetic Dyes

Decolorization of four synthetic dyes: methylene blue, alkaline fuchsin, Coomassie Brilliant Blue, and crystal violet, was performed with the purified KbLcc1 laccase according to our previously described method [29]. The reaction mixture contained acetate buffer (100 mM, pH 3.5), synthetic dye (250 mg/L), purified laccase KbLcc1 (0.1 U), and 1.0 $\mathrm{mM} \mathrm{ABTS}$ as a redox mediator. The mixture was incubated at $30{ }^{\circ} \mathrm{C}$ for $60 \mathrm{~min}$. The decolorization of dye, expressed as dye decolorization percent $(\%)$, was calculated by means of Formula (1):

$$
\text { decolorization }(\%)=\left[\left(A_{i}-A_{f}\right) / A_{i}\right] \times 100,
$$

where $A_{i}$ is the initial concentration of the dye and $A_{f}$ the final concentration of the dye. All reactions were performed in triplicates.

\subsubsection{Biotransformation of Ferulic Acid into Vanillin}

The recombinant KbLcc1 enzyme was used in a biotransformation of ferulic acid into vanillin. The reactions were carried out under various conditions. The reaction mixture contained phosphate buffer (100 mM, pH 7.0) or acetate buffer (100 mM, pH 3.5), ferulic acid as a substrate (in the final concentrations of $1 \mathrm{mM}$ or $10 \mathrm{mM}$ ), $0.1 \mathrm{U}$ of the purified recombinant laccase KbLcc1, and no or $1 \mathrm{mM}$ of ABTS added as redox mediator. The mixture was incubated at $20^{\circ} \mathrm{C}$ or $30{ }^{\circ} \mathrm{C}$ for 5 days. The reaction products were extracted with methylene chloride $(1: 1, v / v)$ and organic phase was analyzed by gas chromatography coupled to mass spectrometry (GC-MS). Molar yield was calculated as the ratio between the produced vanillin $(\mathrm{mM})$ and the initial ferulic acid $(\mathrm{mM})$.

\subsection{Analytical Methods}

Laccase activity was determined by analysis of the oxidation of ABTS [67]. The nonphenolic dye ABTS is oxidized by laccase to the more stable and preferred state of the cation radical. The concentration of the cation radical responsible for the intense blue-green 
color can be correlated to the enzyme activity and is measured at $420 \mathrm{~nm} \mathrm{[68]} \mathrm{at} 30{ }^{\circ} \mathrm{C}$. The assay mixture contained $1.0 \mathrm{mM}$ ABTS, $100 \mathrm{mM}$ acetate buffer (pH 3.5), and a suitable amount of enzyme. Oxidation of ABTS was monitored by determining the increase in $\mathrm{A}_{420}$ $\left(\varepsilon_{420}, 3.6 \times 10^{4} \mathrm{M}^{-1} \mathrm{~cm}^{-1}\right)$ for $10 \mathrm{~min}$. One unit (U) was defined as the amount of the laccase that oxidized $1 \mu \mathrm{mol}$ of ABTS substrate per min.

Protein concentration was determined according to Bradford [69] using BSA as a standard.

Determination of vanillin concentration was performed using the GC-MS spectrometer Pegasus 4 D (LECO, St. Joseph, MI, USA). The chromatography column used was StabilwaxDA (Restek, Bellefonte, PA, USA) (length of the column $30 \mathrm{~m}$, inner diameter $0.25 \mathrm{~mm}$, thickness of the film of the stationary phase $0.25 \mu \mathrm{m})$. The temperature of the injector was equal to the temperature of the transfer lane $\left(250^{\circ} \mathrm{C}\right)$. The temperature program of the column oven was set from $50{ }^{\circ} \mathrm{C}$ (isotherm $1 \mathrm{~min}$ ) to $240{ }^{\circ} \mathrm{C}$ (isotherm $15 \mathrm{~min}$ ) with a temperature rise of $4^{\circ} \mathrm{C} / \mathrm{min}$. Helium gas was used as a carrier gas with the constant flow of $1 \mathrm{~mL} / \mathrm{min}$. The mass spectrometer was set to Electron Impact mode, with the temperature of the ion source equal to $200^{\circ} \mathrm{C}$, and the energy of ionization $70 \mathrm{eV}$.

\subsection{Statistical Analysis}

Calculations were performed using Microsoft Excel version 2007 (Microsoft Corporation, Redmond, WA, USA). Experimental values were reported as the means \pm s.e. Statistical significance of the data was assessed by analysis of variance $(p<0.05)$ using the MiniTab19 software (MiniTab Lt, Coventry, UK, Software; www.minitab.com/en-us / products/minitab/, accessed on 10 June 2021). For significant differences, the Tukey method of multiple comparisons was performed. Graphs were plotted using SigmaPlot version 11 (Chicago, IL, USA) and Graph Pad Prism5 (version 5.00, San Diego, CA, USA).

\section{Conclusions}

The conducted research reported the identification, splicing in vitro, and heterologous expression of the new laccase KbLcc1 gene from K. bupleuri G3 IBMiP in P. pastoris. KbLcc1 laccase possesses interesting enzymatic properties (low optimal temperature, broad $\mathrm{pH}$ range, and organic solvent tolerance) which predetermine its application in organic synthesis reactions. Moreover, increased stability in the presence of $\mathrm{Ca}^{2+}$ and $\mathrm{Mg}^{2+}$ ions could be an advantage in processes taking several days and in the long-term storage of the enzyme. The recombinant laccase was proven to be more efficient in the decolorization of the synthetic dyes than its native counterpart, reaching almost $50 \%$ yields (for crystal violet). It is worth emphasizing that, so far, no application of laccases in the biotransformation of vanillin has been described in the literature. For the first time, this research presented the results of the bioconversion of ferulic acid to vanillin by the recombinant KbLcc1 laccase. This process requires further studies, especially in terms of the reaction mechanism. It is necessary to conduct more detailed experiments aimed at tracing the intermediate and side products formed in the reaction.

Supplementary Materials: The following are available online at https: / www.mdpi.com/article/ 10.3390/ijms22179593/s1, Table S1: Optimal temperature for laccase reaction with syringaldazine, guaiacol and sinapic acid, Table S2: Data to substrate specificity of laccase KbLcc1 reaction with ABTS, Table S3: Data to substrate specificity of laccase KbLcc1 reaction with syringaldazine, Table S4: Data to substrate specificity of laccase KbLcc1 reaction with guaiacol, Table S5: Data to substrate specificity of laccase KbLcc1 reaction with sinapic acid, Figure S1: Influence of $\mathrm{Cu}^{2+}$ ions supplementation of expressing medium BMMY on recombinant laccase activity after 7 days of cultivation of Pichia pastoris, Figure S2: Stability of recombinant laccase KbLcc1 activity after 10 days of incubation in the presence of various metal ions, Figure S3: GC-MS chromatograms of vanillin after $24 \mathrm{~h}$ biotransformation of ferulic acid by laccase KbLcc1, Figure S4: GC-MS chromatograms of vanillin after $48 \mathrm{~h}$ biotransformation of ferulic acid by laccase KbLcc1, Figure S5: GC-MS chromatograms of vanillin after $72 \mathrm{~h}$ biotransformation of ferulic acid by laccase KbLcc1, Figure S6: GC-MS chromatograms of vanillin 
after $96 \mathrm{~h}$ biotransformation of ferulic acid by laccase KbLcc1, Figure S7: GC-MS chromatograms of vanillin after $120 \mathrm{~h}$ biotransformation of ferulic acid by laccase KbLcc1.

Author Contributions: Conceptualization, A.M.B. and K.M.W.; performing of experiments, K.M.W.; writing-original draft preparation, K.M.W., A.T.-C. and A.M.B.; writing—review and editing, A.T.-C. All authors have read and agreed to the published version of the manuscript.

Funding: This research was funded by The Fund of Young Science Leaders at the Faculty of Biotechnology and Food Sciences, Lodz University of Technology.

Acknowledgments: Special acknowledgments to Katarzyna Kubiak for sequencing of K. bupleuri G3 IBMiP genome, to Małgorzata Ryngajłło for assembly of the sequenced genome of K. bupleuri G3 IBMiP, and to Radosław Bonikowski for conducting the GC-MS analyses.

Conflicts of Interest: The authors declare no conflict of interest. The funders had no role in the design of the study; in the collection, analyses, or interpretation of data; in the writing of the manuscript, or in the decision to publish the results.

\section{References}

1. Klonowska, A.; Gaudin, C.; Fournel, A.; Asso, M.; Le Petit, J.; Giorgi, M.; Tron, T. Characterization of low redox potential laccase from the basidiomycete C30. Eur. J. Biochem. 2002, 269, 6119-6125. [CrossRef] [PubMed]

2. Rivera-Hoyos, C.M.; Morales-Alvarez, E.D.; Poutou-Pinales, R.A.; Pedroza-Rodriguez, A.M.; Rodriguez-Vazquez, R.; DelgadoBoada, J.M. Fungal laccases. Fungal Biol. Rev. 2013, 37, 67-82. [CrossRef]

3. Mate, D.M.; Alcalde, M. Laccase engineering: From rational design to directed evolution. Biotechnol. Adv. 2015, 33, 25-40. [CrossRef] [PubMed]

4. Pourmir, A.; Johannes, T.W. Directed evolution: Selection of the host organism. Comput. Struct. Biotechnol. J. 2012, 2, e201203012. [CrossRef] [PubMed]

5. Piscitelli, A.; Pezzella, C.; Giardina, P.; Faraco, V.; Sannia, G. Heterologous laccase production and its role in industrial applications. Bioeng. Bugs 2010, 1, 252-262. [CrossRef] [PubMed]

6. Balakshin, M.; Chen, C.L.; Gratzl, J.S.; Kirkman, A.G.; Jacob, H. Biobleaching of pulp with dioxygen in laccase-mediator system-Effect of variables on the reaction kinetics. J. Mol. Catal. B Enzym. 2001, 16, 205-215. [CrossRef]

7. Minussi, R.C.; Rossi, M.; Bologna, L.; Rotilio, D. Phenols removal in musts: Strategy for wine stabilization by laccase. J. Mol. Catal. B Enzym. 2007, 45, 102-107. [CrossRef]

8. Wang, G.D.; Li, Q.J.; Luo, B.; Chen, X.Y. Ex planta phytoremediation of trichlorophenol and phenolic allelo chemicals via an engineered secretory laccase. Nat. Biotechnol. 2004, 22, 893-897. [CrossRef]

9. Spina, F.; Cordero, C.; Schilliro, T.; Sgorbini, B.; Pignata, C.; Gilli, G.; Bicci, C.; Varese, G.C. Removal of micropollutants by fungal laccases in model solution and municipal wastewater: Evaluation of estrogenic activity and ecotoxicity. J. Clean Prod. 2015, 100, 185-194. [CrossRef]

10. Watharkar, A.D.; Kadam, S.K.; Khandare, R.V.; Kolekar, P.D.; Jeon, B.H.; Jadhav, J.P.; Govindwar, S.P. Asparagus densiflorus in a vertical subsurface flow phytoreactor for treatment of real textile effluent: A lab to land approach for in situ soil remediation. Ecotoxicol. Environ. Saf. 2018, 161, 70-77. [CrossRef]

11. Liu, H.; Cheng, Y.; Du, B.; Tong, C.; Liang, S.; Han, S.; Zheng, S.; Lin, Y. Overexpression of a novel thermostable and chloridetolerant laccase from Thermus thermophilus SG0.5 JP17-16 in Pichia pastoris and its application in synthetic dye decolorization. PLoS ONE 2015, 10, e0119833. [CrossRef]

12. Huang, M.T.; Lu, Y.C.; Zhang, S.; Lu, F.; Yang, H. Rice (Oryza sativa) laccases involved in modification and detoxification of herbicides atrazine and izoproturon residues in plants. J. Agric. Food Chem. 2016, 64, 6397-6406. [CrossRef]

13. Zheng, J.; Zhu, Q.; Wu, Y.; Lin, X. Oxidation of polycyclic aromatic hydrocarbons using Bacillus CotA with high laccase activity and copper independence. Chemosphere 2016, 148, 1-7. [CrossRef]

14. Jahangiri, E.; Thomas, I.; Schulze, A.; Seiwert, B.; Cabana, H.; Schlosser, D. Characterization of electron beam irradiationimmobilised laccase for application in wastewater treatment. Sci. Total Environ. 2018, 624, 309-322. [CrossRef]

15. Fabbrini, M.; Galli, C.; Gentili, P.; Macchitella, D. An oxidation of alcohols by oxygen with the enzyme laccase and mediation by TEMPO. Tetrahedron Lett. 2001, 42, 7551-7553. [CrossRef]

16. Nicotra, S.; Cramaross, M.R.; Mucci, A.; Pagnoni, U.M.; Riva, S.; Forti, L. Biotransformation of resveratrol: Synthesis of trans-dehydrodimers catalyzed by laccases from Myceliophtora thermophyla and from Trametes pubescens. Tetrahedron 2004, 60, 595-600. [CrossRef]

17. Kurisawa, M.; Chung, J.E.; Uyama, H.; Kobayashi, S. Laccase-catalyzed synthesis and antioxidant property of poly(catechin). Macromol. Biosci. 2003, 3, 758-764. [CrossRef]

18. Kurisawa, M.; Chung, J.E.; Uyama, H.; Kobayashi, S. Oxidative coupling of epigallocatechin gallate amplifies antioxidant activity and inhibits xanthine oxidase activity. Chem. Commun. 2004, 3, 294-295. [CrossRef]

19. Anderson, J.S. The chemistry of hair colorants. J. Soc. Dyers Colour. 2000, 116, 193-196. 
20. Kim, S.; Lopez, C.; Guebitz, G.; Cavaco-Paulo, A. Biological coloration of flax fabrics with flavonoids using laccase from Trametes hirsute. Eng. Life Sci. 2008, 8, 324-330. [CrossRef]

21. Mustafa, R.; Muniglia, L.; Rovel, B.; Girardin, M. Phenolic colorants obtained by enzymatic synthesis using a fungal laccase in a hydro-organic biphasic system. Food Res. Int. 2015, 38, 995-1000. [CrossRef]

22. Gallage, N.J.; Møller, B.L. Vanilla: The most popular flavour. In Biotechnology of Natural Products; Schwab, W., Lange, B., Wüst, M., Eds.; Springer: Cham, Switzerland, 2018; pp. 3-23. [CrossRef]

23. Chattopadhyay, P.; Banerjee, G.; Sen, S.K. Cleaner production of vanillin through biotransformation of ferulic acid esters from agro residue by Streptomyces sannanensis. J. Clean Prod. 2018, 182, 272-279. [CrossRef]

24. Tang, P.L.; Hassan, O. Bioconversion of ferulic acid attained from pineapple peels and pineapple crown leaves into vanilic acid and vanillin by Aspergillus niger I-1472. BMC Chem. 2020, 14, 7. [CrossRef]

25. Chen, P.; Yan, L.; Zhang, S.; Wu, Z.; Li, S.; Yan, X.; Wang, N.; Liang, N.; Li, H. Optimizing bioconversion of ferulic acid to vanillin by Bacillus subtilis in the stirred packed reactor using Box-Behnken design and desirability function. Food Sci. Biotechnol. 2017, 26, 143-152. [CrossRef]

26. Perez-Rodriguez, N.; de Souza Oliveira, R.P.; Agrasar, A.M.; Dominguez, J.M. Ferulic acid transformation into the main vanilla aroma compounds by Amycolatopsis sp. ATCC 39116. Appl. Microbiol. Biotechnol. 2016, 100, 1677-1689. [CrossRef]

27. Falconnier, B.; Lapierre, C.; Lesage-Meessen, L.; Yonnet, G.; Brunerie, P.; Colonna-Ceccaldi, B.; Corrieu, G.; Asther, M. Vanillin as a product of ferulic acid biotransformation by the white-rot fungus Pycnoporus cinnabarinus I-937: Identification of metabolic pathways. J. Biotechnol. 1994, 37, 123-132. [CrossRef]

28. Furuya, T.; Miura, M.; Kuroiwa, M.; Kino, K. High-yield production of vanillin from ferulic acid by a coenzyme-independent decarboxylase/oxygenase two-stage process. N. Biotechnol. 2015, 32, 335-339. [CrossRef]

29. Wiśniewska, K.M.; Twarda-Clapa, A.; Białkowska, A.M. Screening of novel laccase producers-Isolation and characterization of cold-adapted laccase from Kabatiella bupleuri G3 capable of synthetic dye decolorization. Biomolecules 2021, 11, 828. [CrossRef]

30. Heckman, K.L.; Pease, L.R. Gene splicing and mutagenesis by PCR-driven overlap extension. Nat. Protoc. 2007, 2, 924-932. [CrossRef]

31. Viswanath, B.; Rajesh, B.; Janardhan, A.; Kumar, A.P.; Narasimha, G. Fungal laccases and their application in bioremediation. Enzyme Res. 2014, 2014, 163242. [CrossRef]

32. Pinar, O.; Tamerler, C.; Yazgan Karatas, A. Heterologus expression and characterization of a high redox potential laccase from Coriolopsis polyzona MUCL 38443. Turk. J. Biol. 2017, 41, 278-291. [CrossRef]

33. Bao, S.; Teng, Z.; Ding, S. Heterologous expression and characterization of a novel laccase isoenzyme with dyes decolorization potential from Coprinus comatus. Mol. Biol. Rep. 2013, 40, 1927-1936. [CrossRef]

34. Li, Q.; Pei, J.; Zhao, L.; Xie, J.; Cao, F.; Wang, G. Overexpression and characterization of laccase from Trametes versicolor in Pichia pastoris. Appl. Biochem. Microbiol. 2014, 50, 140-147. [CrossRef]

35. Wang, B.; Yan, Y.; Tian, Y.; Zhao, W.; Li, Z.; Gao, J.; Peng, R.; Yao, Q. Heterologous expression and characterization of a laccase from Colletotrichum lagenarium and decolourisation of different synthetic dyes. World J. Microbiol. Biotechnol. 2016, 32, 40. [CrossRef]

36. Arregui, L.; Ayala, M.; Gomez-Gil, X.; Gutierrez-Soto, G.; Hernandez-Luna, C.E.; de los Santos, M.H.; Levin, L.; Rojo-Dominguez, A.; Romero-Martinez, D.; Saparrat, M.C.; et al. Laccase: Structure, function, and potential application in water bioremediation. Microb. Cell Factories 2019, 18, 200. [CrossRef]

37. Atalla, M.M.; Zeinab, H.K.; Eman, R.H.; Amani, A.Y.; Abeer, A.E. Characterization and kinetic properties of the purified Trematosphaeria mangrovei laccase enzyme. Saudi J. Biol. Sci. 2013, 20, 373-381. [CrossRef]

38. Maestre-Reyna, M.; Liu, W.C.; Jeng, W.Y.; Lee, C.C.; Hsu, C.A.; Wen, T.N.; Wang, A.H.; Shyur, L.F. Structural and functional roles of glycosylation in fungal laccase from Lentinus sp. PLOS ONE 2015, 10, e0120601. [CrossRef]

39. Rich, J.O.; Leathers, T.D.; Anderson, A.M.; Bischoff, K.M.; Manitchotpisit, P. Laccases from Aureobasidium pullulans. Enzyme Microb. Technol. 2013, 53, 33-37. [CrossRef]

40. Aung, T.; Jiang, H.; Chen, C.C.; Liu, G.L.; Hu, Z.; Chi, Z.M.; Chi, Z. Production, gene cloning and overexpression of a laccase in the marine-derived yeast Aureobasidium melanogenum strain 11-1 and characterization of the recombinant laccase. Mar. Biotechnol. 2019, 21, 76-87. [CrossRef]

41. Rich, J.O.; Manitchotpisit, P.; Peterson, S.W.; Leathers, T.D. Laccase production by diverse phylogenetic clades of Aureobasidium pullulans. RJAS 2011, 1, 41-47.

42. Mtibaà, R.; Barriuso, J.; de Eugenio, L.; Aranda, E.; Belbahri, L.; Nasri, M.; Martínez, M.J.; Mechichi, T. Purification and characterization of a fungal laccase from the ascomycete Thielavia sp. and its role in the decolorization of a recalcitrant dye. Int. J. Biol. Macromol. 2018, 120, 1744-1751. [CrossRef]

43. Kumari, A.; Kishor, N.; Guptasarma, P. Characterization of a mildly alkalophilic and thermostable recombinant Thermus thermiphilus laccase with applications in decolourization of dyes. Biotechnol. Lett. 2018, 40, 285-295. [CrossRef]

44. Baldrian, P. Fungal laccases-Occurrence and properties. FEMS Microbiol. Rev. 2006, 30, 215-242. [CrossRef]

45. Kiiskinen, L.L.; Viikari, L.; Kruus, K. Purification and characterization of a novel laccase from the ascomycete Melanocarpus albomyces. Appl. Microbiol. Biotechnol. 2002, 59, 198-204. [CrossRef]

46. Chen, S.; Ge, W.; Buswell, J.A. Biochemical and molecular characterization of a laccase from the edible straw mushroom, Volvariella volvacea. Eur. J. Biochem. 2004, 271, 318-328. [CrossRef] 
47. Yang, Y.; Ding, Y.; Liao, X.; Cai, Y. Purification and characterization of a new laccase from Shiraia sp. SUPER-H168. Process Biochem. 2013, 48, 351-357. [CrossRef]

48. Singhal, A.; Choudhary, G.; Thakur, I.S. Characterization of laccase activity produced by Cryptococcus albidus. Prep. Biochem. Biotechnol. 2012, 42, 113-124. [CrossRef]

49. Yang, Q.; Zhang, M.; Zhang, M.; Wang, C.; Liu, Y.; Fan, X.; Li, H. Characterization of a novel, cold-adapted and thermostable laccase-like enzyme with high tolerance for organic solvents and salt and potent dye decolorization ability, derived from a marine metagenomic library. Front. Microbiol. 2018, 9, 2998. [CrossRef]

50. Cavicchioli, R.; Charlton, T.; Ertan, H.; Mohd Omar, S.; Siddiqui, K.S.; Williams, T.J. Biotechnological uses of enzymes from psychrophiles. Microb. Biotechnol. 2011, 4, 449-460. [CrossRef]

51. You, L.F.; Liu, Z.M.; Lin, J.F.; Guo, L.Q.; Huang, X.L.; Yang, H.X. Molecular cloning of a laccase gene from Ganoderma lucidum and heterologous expression in Pichia pastoris. J. Basic Microbiol. 2014, 54, 134-141. [CrossRef] [PubMed]

52. An, H.; Xiao, T.; Fan, H.; Wei, D. Molecular characterization of a novel thermostable laccase PLLCC2 from the brown rot fungus Postia placenta MAD-698-R. Electron. J. Biotechnol. 2015, 18, 451-458. [CrossRef]

53. Mandic, M.; Djokic, L.; Nikolaivits, E.; Prodanovic, R.; O'Connor, K.; Jeremic, S.; Topakas, E.; Nikodinovic-Runic, J. Identification and characterization of new laccase biocatalysts from Pseudomonas species suitable for degradation of synthetic textile dyes. Catalysts 2019, 9, 699. [CrossRef]

54. Kumar, V.P.; Naik, C.; Sridhar, M. Production, purification and characterization of novel laccase produced by Schizophyllum commune NI-07 with potential for delignification of crop residues. Appl. Biochem. Microbiol. 2015, 51, 432-441. [CrossRef]

55. Younes, S.B.; Sayadi, S. Purification and characterization of a novel trimeric and thermotolerant laccase produced from the ascomycete Scytalidium thermophilum strain. J. Mol. Catal. B Enzym. 2011, 73, 35-42. [CrossRef]

56. Sondhi, S.; Kaur, R.; Madan, J. Purification and characterization of a novel white highly thermo stable laccase from a novel Bacillus sp. MSK-01 having potential to be used as anticancer agent. Int. J. Biol. Macromol. 2021, 170, 232-238. [CrossRef]

57. Ramirez-Cavazos, L.I.; Junghanns, C.; Ornelas-Soto, N.; Cardenas-Chaves, D.L.; Hernandez-Luna, C.; Demarche, P.; Enaud, E.; Garcia-Morales, R.; Agathos, S.N.; Parra, R. Purification and characterization of two thermostable laccases from Pycnoporus sanguineus and potential role in degradation of endocrine disrupting chemicals. J. Mol. Catal. B Enzym. 2014, 108, 32-42. [CrossRef]

58. Chauhan, A.K.; Choudhury, B. Suitability of organic solvent and cholinium based ionic liquid activated novel lignolytic enzymes of H. aswanensis for enhanced Kalson lignin degradation. Int. J. Biol. Macromol. 2020, 165, 107-117. [CrossRef]

59. Ezike, T.C.; Ezugwu, A.L.; Udeh, J.O.; Eze, S.O.; Chilaka, F.C. Purification and characterisation of new laccase from Trametes polyzona WRF03. Biotechnol. Rep. 2020, 28, e00566. [CrossRef]

60. Jafari, M.; Mojtabavi, S.; Faramarzi, M.A.; Mehrnejad, F.; Soleimani, M.; Mirjani, R. Molecular level insight into stability, activity and structure of laccase in aqueous ionic liquid and organic solvents: An experimental and computational research. J. Mol. Liq. 2020, 317, 113925. [CrossRef]

61. Benghazi, L.; Record, E.; Suarez, A.; Gomez-Vidal, J.A.; Martinez, J.; de la Rubia, T. Production of the Phanerochaete flavido-alba laccase in Aspergillus niger for synthetic dyes decolorization and biotransformation. World J. Microbiol. Biotechnol. 2014, 30, 201-211. [CrossRef]

62. Lu, L.; Zhang, B.B.; Yu, S.Y.; Bian, X.J.; Wang, W.; Wang, Y. Purification and characterization of laccase from Pycnoporus sanguineus and decolorization of an anthraquinone dye by the enzyme. Appl. Microbiol. Biotechnol. 2007, 74, 1232-1239. [CrossRef] [PubMed]

63. Lu, L.; Zhao, M.; Liang, S.C.; Zhao, L.Y.; Li, D.B.; Zhang, B.B. Production and synthetic dyes decolourization capacity of a recombinant laccase from Pichia pastoris. J. Appl. Microbiol. 2009, 107, 1149-1156. [CrossRef] [PubMed]

64. Priefert, H.; Rabenhorst, J.; Steinbuchel, A. Biotechnological production of vanillin. Appl. Microbiol. Biotechnol. 2001, 56, 296-314. [CrossRef]

65. Wellington, K.W. Application of laccases in organic synthesis: A review. In Green Chemistry; Luque, R., Ed.; Nova Science Publishers, Inc.: Hauppauge, NY, USA, 2011; pp. 1-44.

66. Bankevich, A.; Nurk, S.; Antipov, D.; Gurevich, A.A.; Dvorkin, M.; Kulikov, A.S.; Lesin, V.M.; Nikolenko, S.I.; Pham, S.; Prijbelski, A.D.; et al. SPAdes: A new genome assembly algorithm and its applications to single-cell sequencing. J. Comput. Biol. 2012, 19, 455-477. [CrossRef]

67. Bourbonnais, R.; Leech, D.; Paice, M.G. Electrochemical analysis of the interactions of laccase mediators with lignin model compounds. Biochim. Biophys. Acta 1998, 1379, 381-390. [CrossRef]

68. Majcherczyk, A.; Johannes, C.; Huttermann, A. Oxidation of polycyclic aromatic hydrocarbons (PAH) by laccase of Trametes versicolor. Enzyme Microb. Technol. 1998, 22, 335-341. [CrossRef]

69. Bradford, M.M. A rapid and sensitive method for the quantitation of microgram quantities of protein utilizing the principle of protein dye binding. Anal. Biochem. 1976, 72, 248-254. [CrossRef] 